\title{
Seaweeds, Intact and Processed, as a Valuable Component of Poultry Feeds
}

\author{
Izabela Michalak ${ }^{1, *(1)}$ and Khalid Mahrose $2, *$ (B) \\ 1 Faculty of Chemistry, Department of Advanced Material Technologies, Wrocław University of Science and \\ Technology, Smoluchowskiego 25, 50-372 Wrocław, Poland \\ 2 Animal and Poultry Production Department, Faculty of Technology and Development, Zagazig University, \\ Zagazig 44511, Egypt \\ * Correspondence: izabela.michalak@pwr.edu.pl (I.M.); ostrichkhalid@zu.edu.eg (K.M.); \\ Tel.: +48-713202434 (I.M.); +20-1001278452 (K.M)
}

Received: 1 July 2020; Accepted: 14 August 2020; Published: 18 August 2020

check for updates

\begin{abstract}
Poultry production is an important area of the agricultural economy. Nowadays, there is an interest in novel sources of feed additives that will improve production performance and poultry health. As an easily available and renewable biomass rich in biologically active compounds, seaweeds can meet this demand. Different forms of seaweeds-seaweed powder from naturally occurring biomass, cultivated or waste biomass, extracted compounds, post-extraction residues or liquid extracts-may be used in poultry feeding. Inclusion of this unconventional material in the poultry nutrition can positively influence the poultry performance along with its health and enrich poultry products with active compounds, such as micro- and macroelements, polyunsaturated fatty acids and pigments. Seaweeds also reduce lipids and cholesterol in eggs. Moreover, due to their unique properties, they can serve as an alternative to antibiotic growth promoters. This review presents the latest developments in the use of seaweeds in poultry nutrition, as well as its limitations.
\end{abstract}

Keywords: poultry; seaweeds; active compounds; poultry performance; health status; food enrichment

\section{Introduction}

Poultry production is an important agricultural subsector in many countries. Poultry are birds which render economic services to humans as a primary supplier of meat, egg and raw materials for different industries (feather, waste products, etc.), source of income and employment to people when compared to other domestic animals [1]. According to USDA (2020), the world chicken meat production in 2020 increased than previous years. In July 2020, the total production of meat reached 100,026 metric tons, whereas in July 2019 it was 99,027 metric tons-an increase of nearly 1\%. The demand for poultry meat will increase because in the face of the economic crisis customers are looking for cheaper animal protein. The total world consumption of chicken meat reached 97,908 metric tons in July 2020, whereas in July 2019-97,127 metric tons [2]. Poultry is efficient in converting feed into high-value products within a comparably short period [3-5]. Eggs and poultry meat are beginning to make a substantial contribution to relieving the protein insufficiency in many countries [6,7]. In today's poultry industry, practices regarding management and feeding (composition, systems) are among the most important factors [8-14].

Currently, there is an interest in the application of seaweeds in poultry nutrition. Seaweeds (called also macroalgae), which include green (Chlorophyceae), brown (Phaeophyceae) and red algae (Rhodophyceae), are a naturally occurring source of the biomass that develops in variable environments (results also from eutrophication) and is easily cultivated [15]. Seaweeds as a rich source of bioactive compounds when included into feed can improve poultry health and performance as well as increase 
the quality of poultry products (eggs, meat) $[16,17]$. According to the Commission Regulation (EU) No 575/2011 of 16 June 2011, algae in different forms are listed in the catalog of feed materials, which contains: "algae-live or processed, regardless of their presentation, including fresh, chilled or frozen algae", "dried algae-product obtained by drying algae" that "may have been washed to reduce the iodine content", "algae meal-product of algae oil manufacture, obtained by extraction of algae", "algal oil—product of the oil manufacture from algae obtained by extraction", "algae extract—watery or alcoholic extract of algae that principally contains carbohydrates", "seaweed meal—product obtained by drying and crushing macroalgae, in particular brown seaweed" that "may have been washed to reduce the iodine content". What is important, the name of the feed material should be supplemented by the species.

The literature data show that seaweeds in poultry nutrition are used in both forms: as a feed material and a feed additive. According to the Commission Regulation (EU) No 767/2009 of 13 July 2009 on the placing on the market and use of feed, "feed materials - means products of vegetable or animal origin, whose principal purpose is to meet animals' nutritional needs, in their natural state, fresh or preserved and products derived from the industrial processing thereof and organic or inorganic substances, whether or not containing feed additives, which are intended for use in oral animal-feeding either directly as such or after processing or in the preparation of compound feed or as carrier of premixtures". "Feed additives" according to Regulation (EC) No 1831/2003 of 22 September 2003 on additives for use in animal nutrition are defined as "substances, microorganisms or preparations, other than feed material and premixtures, which are intentionally added to feed or water in order to perform, in particular, one or more of the functions": they "(1) favorably affect the characteristics of feed, (2) favorably affect the characteristics of animal products, (3) favorably affect the color of ornamental fish and birds, (4) satisfy the nutritional needs of animals, (5) favorably affect the environmental consequences of animal production, (6) favorably affect animal production, performance or welfare, particularly by affecting the gastrointestinal flora or digestibility of foodstuffs or (7) have a coccidiostatic or histomonostatic effect". In the European Union feed legislation, intact seaweeds or macroalgae are considered "feed material" not requiring registration, while "extracts" of seaweeds are recognized as "feed additives" requiring an EC authorization act before legal use in animal feeding within the EU.

Macroalgae can be not only a part of the strategy to look for new, natural, ecological and healthy feed materials and/or feed additives, but also for the production of designer poultry products (eggs, meat) enriched with biologically active compounds (e.g., polyunsaturated fatty acids, polyphenols, polysaccharides, pigments, vitamins, amino acids, etc.,) with functional attributes, such as antimicrobial, antioxidant, anti-inflammatory, etc. [16-18]. Consumption of such food can be beneficial to human health. Seaweeds can also be considered as a promising alternative to conventional terrestrial resources used for the production of feed materials/feed additives [19]. Locally available materials, such as seaweeds, can reduce feed cost [20].

In the literature, there are several review articles or book chapters on the use of seaweeds in animal feeding [15,21-25], and a few of them are dedicated to particular species of animals, for example: ruminants (sheep, lambs, goats, cows, calves) [22]; pigs [19,22,23]; rabbits [22]; poultry (broilers, laying hens) [22,26,27]; horses [24]. Literature data confirm that seaweeds can play an important role in the animal feeding, but there is no detailed analysis of the effects of algae in poultry nutrition. This article arrays the current state of knowledge in this field. Appropriately selected seaweeds applied at low inclusion levels can improve not only poultry growth performance and the quality of products, but also their health status (e.g., immune function) due to alteration of gut microbiome and antioxidant properties and can be considered an alternative to antibiotic growth promoters (AGP) used in poultry production [21,28-36]. Most often, seaweeds are used as feed additives for hens and broilers, but there are also a few reports on their application in duck $[30,37,38]$, Japanese quail $[39,40]$ and cockerel [41] feeding. 


\section{Seaweeds Biologically Active Compounds Important in Poultry Nutrition}

The nutritional value of seaweeds is highly variable and depends on many factors such as species, maturity, habitat, geographical origin, area of cultivation, season, harvest time, environmental and physiological variations, water temperature, etc. [19,20,42]. Seaweeds that are most frequently used or recommended for poultry feeding are presented in Figure 1.

\begin{tabular}{|l|}
\hline Chaetomorpha antennina [39] \\
\hline \hline Cladophora sp. [43] \\
\hline \hline Codium adhaerens [15] \\
Codium vermilara [15] \\
\hline \hline Enteromorpha sp. [44,45] \\
Enteromorpha prolifera [43,46] \\
\hline Ulva sp. [15,47] \\
Ulva fasciata [40] \\
Ulva rigida [41,48] \\
Ulva lactuca [49] \\
\hline
\end{tabular}

\begin{tabular}{|l|}
\hline Chondrus crispus [31,50] \\
\hline \hline Gigartina sp. [15] \\
\hline \hline Gracilaria sp. [38] \\
Gracilaria vermiculophylla [15] \\
Gracilaria corticata [39] \\
\hline
\end{tabular}

\section{Kappaphycus alvarezii $[18,51]$}

Palmaria palmata [33]

Polysiphonia spp. [37,52]

Sarcodiotheca gaudichaudii [31]
Ascophyllum nodosum

$[21,22,50,53,54]$

\begin{tabular}{|l|}
\hline Bifurcaria bifurcata [15] \\
\hline \hline Cystoseira usneoides [15] \\
\hline
\end{tabular}

Fucus guiryi [15]

Fucus serratus $[15,55]$

Fucus spiralis [15]

Fucus vesiculosus [55]

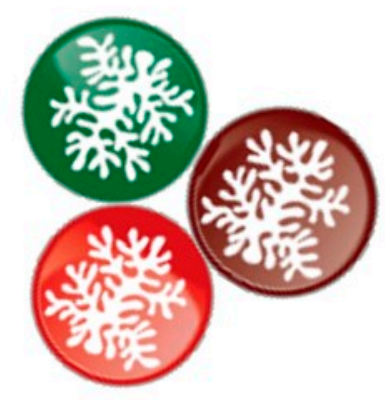

Hizikia fusiforme $[32,35]$

Laminaria ochroleuca [15]

Laminaria japonica [30, 36]

Macrocystis pyrifera [44,45]

and residue after alginate

extraction [56]

Pelvetia canaliculata [15]

Saccharina latissima [15]

Sargassum spp. [57,58]

Sargassum muticum $[15,20]$

Sargassum vulgare [15]

Sargassum sinicola $[44,45]$

Sargassum cinereum [40]

Sargassum binderi $[59,60]$

Sargassum dentifebium $[61,62]$

Sargassum wightii [39,63]

Undaria pinnatifida $[32,35]$

Figure 1. Examples of seaweeds used in poultry feeding $[15,18,20-22,30-33,35-41,43-63]$.

The authors cited in this text presented the chemical composition of individual algae species. As can be seen from Figure 1, brown seaweeds are most frequently applied in poultry feeding. This coincides with the general trend of using mainly brown algae in animal nutrition. Makkar et al. (2016) showed that among main seaweed species used as a component of animal feed, brown-Ascophyllum nodosum, Macrocystis pyrifera, Laminaria and Sargassum, red-Palmaria palmata and Lithothamnion and green species-Ulva were dominant [22].

The unique nutritional composition of various seaweed species is of particular importance in poultry nutrition. Seaweeds contain polysaccharides (brown algae: alginate, cellulose, fucoidan, laminarin; red: agar, carrageenan, cellulose, porphyran, xylan; green: cellulose, inulin, pectin, xylan, ulvan), proteins, essential amino acids, minerals $(\mathrm{K}, \mathrm{Ca}, \mathrm{Mg}, \mathrm{Zn}, \mathrm{Cu}, \mathrm{Co}, \mathrm{I}, \mathrm{B})$, vitamins $\left(\mathrm{B}_{12}, \mathrm{~K}\right.$, C, E, A, D), lipids, polyunsaturated fatty acids (PUFA), pigments such as carotenoids (carotene xanthophyll), chlorophylls, phycobilins (e.g., phycoerythrin) and many antioxidant compounds, 
including mainly polyphenols $[16,17,19]$. These bioactive molecules show prebiotic, antimicrobial (antibacterial, antifungal, antivirus), antioxidant, anti-inflammatory immunomodulatory effects $[17,23]$. Detailed characteristics of many seaweed species are presented in review papers, for example: Fleurence (1999) [64]; Holdt and Kraan (2011) [16]; Cabrita et al. (2016) [15]; Øverland et al. (2019) [19]; Makkar et al. (2016) [22]; Corino et al. (2019) [23].

Seaweeds have great potential to be used as feed additives containing minerals, especially $\mathrm{Ca}$, $\mathrm{Mg}, \mathrm{Fe}, \mathrm{Cu}, \mathrm{I}, \mathrm{Mn}$, Se-and to a lesser extent, $\mathrm{P}$ and $\mathrm{Zn}[15,40]$. The availability of seaweeds chelated micro-metals to animals (including poultry) is higher than that found in inorganic compounds [21,40]. This observation was also confirmed in the work of Michalak et al. (2011), where microelements bound with green seaweeds via biosorption were better bioavailable to laying hens than inorganic salts of these microelements [43]. Due to the high content of micro- and macroelements, seaweeds are proposed as feed additives that can be involved in the prevention of elemental deficiencies, enrich eggs with minerals, enhance eggshell quality and bone mineralization $[43,58]$. Pigments contained in seaweeds can be very important in poultry nutrition and are promoted in poultry production due to their antioxidant potential and usefulness for pigmenting food products [65]. Seaweed polysaccharides due to their prebiotic activities can improve poultry performance, egg quality and overall gut health $[28,31,34,40,48]$. Seaweeds dietary fiber could be an alternative to improve intestinal integrity and reduce concentration of lipids in serum [48]. Marine macroalgae can also serve as a source of polyunsaturated fatty acids in poultry diet and can be an alternative to flaxseed, fish oil, fish meal and canola to enrich eggs and chicken meat with n-3 fatty acids [66]. Carrillo et al. (2008) showed that seaweeds contain several crucial fatty acids such as: linoleic (C18:2, LA), $\alpha$-linolenic (C18:3, ALA), arachidonic (C20:4, AA), eicosapentaenoic (C20:5, EPA), docosahexaenoic (C22:6, DHA) which are important for human health [44].

On the other hand, seaweeds can also contain toxic metals and other compounds like antinutritional factors (e.g., phenolic compounds, polysaccharides) that can limit their application as feed additives $[64,67,68]$. Considering the use of seaweeds as feed additives or feed material, the requirements of Commission Regulation (EU) No 1275/2013 of 6 December 2013 concerning the level of undesirable substance (including toxic metals) in products intended for animal feed should be taken into account. Additionally, "feed materials should be free from chemical impurities resulting from their manufacturing process and from processing aids ... " according to the Regulation (EC) No 183/2005 of 12 January 2005 laying down requirements for feed hygiene. All seaweed species, before application in animal feeing should be examined in terms of their multielemental composition [42].

Seaweeds polysaccharides can serve as prebiotics, but in some cases they can have an antinutritional effect. It is suggested that certain additives (e.g., enzymes) be incorporated into poultry feed to improve the digestibility of algal polysaccharides [41]. In order to limit the influence of fibers as antinutritional factors, Lahaye and Vigoroux (1992) proposed enzymatic pretreatment of Palmaria palmata with

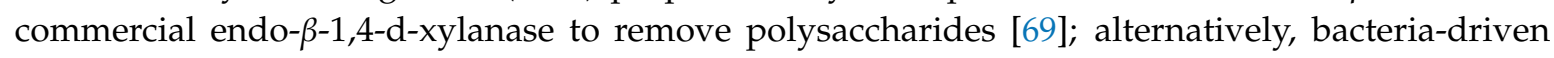
fermentation can be applied to reduce the content of polysaccharides $[32,60]$. Not all algal species have an antinutritive effect. Ventura et al. (1994) showed that the inclusion of 100, 200 and $300 \mathrm{~g}$ of cultivated and then air-dried Ulva rigida per $\mathrm{kg}$ in the diet of the adult cockerels and 3-week-old chickens did not have an antinutritive effect. Added seaweeds did not modify the true metabolizable energy of the rest of the diet [41]. Another issue which should be considered is the chemical composition of seaweeds which can differ not only by a species, but also due to seasonal variations $[19,20,42,64]$.

\section{Forms of Seaweeds in Poultry Feed}

In many coastal areas, seaweeds drift to the shore because of sea or ocean waves and become useless waste [59]. Usually, macroalgae are collected manually from surface water, beach and submerged rocks [44]. After drying (e.g., sun, dryer), seaweeds are milled and used as a feed additive [40,44,55,70]. In order to prepare a valuable feed additive, sun drying is not always the best option because it is responsible for the degradation of carotenoids in seaweeds which are known to enhance the 
color of animal products [44]. Sun-dried seaweeds do not contain vitamin C either because it is extremely sensitive to temperature [71]. Therefore, air drying of seaweeds in shaded areas is advised (e.g., $[11,36,72])$. The laboratory dryer can also be used for this purpose [52,55], but temperatures should not exceed $40^{\circ} \mathrm{C}$, despite the fact that higher temperatures-for example $60^{\circ} \mathrm{C}$ for $72 \mathrm{~h}$-are at times applied [49,52]. Before drying, seaweeds should be washed with fresh water to remove salt, sand particles and epibionts $[37,40,48,59]$. A high salt content can cause diarrhea and poultry death [59,72]. Dewi et al. (2018) showed that the immersion of Sargassum binderi in a flowing river for $15 \mathrm{~h}$ enabled a reduction in the salt and ash content and an increase in the organic matter and crude protein content in the algal biomass [59]. As shown in Table 1, dried and ground seaweeds are the most often used form in poultry feeding.

The second source of seaweeds used in feeding experiments on poultry is waste generated from the algae cultivation, which still has a valuable chemical composition. Frasiska et al. (2016) estimated that about $65-70 \%$ of the total seaweed cultivation (Gracilaria sp. in Indonesia) is waste which has no commercial value and can be converted into feed material for poultry [38]. Ventura et al. (1994) in the feeding experiments on adult cockerels and 3-week-old chicks used green seaweed Ulva rigida, which was cultivated, then washed with fresh water, air-dried ( $85 \%$ dry matter) and finally ground [41].

Before application in poultry feeding, the seaweed biomass is very often subjected to processing, which could positively affect the quality of the feedstuff by improving fiber and nutrient availability [70]. Dewi et al. (2019) proposed fermentation of Sargassum binderi with Bacillus megaterium S245 (inoculum dosage of $1 \%$ ) for nine days in order to reduce the content of polysaccharide-alginate. The high content of alginate in brown seaweeds may have a negative effect on the poultry performance: it can bind nutrients and inhibit their absorption in the gastrointestinal tract [60]. Additionally, fermentation of the feedstuff with microorganisms can improve its nutritional quality and elongate the storage period $[35,60]$. Choi et al. (2014) for fermentation of brown seaweeds-Undaria pinnatifida and Hizikia fusiformis used five different microorganisms: Bacillus subtilis, Pediococcus acidilactici, Pediococcus pentosaceus, Saccharomyces cerevisiae and Aspergillus oryzae, among which B. subtilis and A. oryzae were selected for further research due to the valuable composition of the final feed additive [32]. Because seaweeds are characterized by low digestibility, their fermentation can increase this parameter. Fermentation of seaweeds also enhances their antioxidant, anti-inflammatory and anticoagulant properties [35]. Because of low digestibility, seaweeds and their bioactive compounds (particularly polysaccharides and phenolics) can be treated as prebiotics [48,73], which are defined as "a non-digestible food ingredient that beneficially affects the host by selectively stimulating the growth and/or activity of one or a limited number of bacteria, already established in the colon and thus improves host health" [74]. Seaweed components are resistant to digestion by enzymes present in the gastrointestinal tract and stimulate the growth of beneficial gut bacteria [73].

Besides traditional sun drying, algae can also be boiled or autoclaved as it was presented in the works of Al-Harthi and El-Deek (2012) [70], Al-Harthi and El-Deek (2012) [61] and El-Deek et al. (2011) [62] for Sargassum dentifebium and in the work of El-Deek and Al-Harthi (2009) [58] for Sargassum sp. It was shown that the method of seaweeds processing had a small effect on their chemical composition. What is important is that thermal processing did not change the Sargassum chemical composition and it had absolutely no effect on the content of amino acids and polyunsaturated fatty acids. Even so, it should be taken into account that seaweeds autoclaving, and boiling can change the activity of bioactive compounds. Hence, these seaweed products are not suitable as a replacement of antibiotics. Thermal processing changed the color of Sargassum: algae treated that were autoclaved were darker than boiled algae [62]. Each seaweed processing is an added cost, so feed companies would benefit from minimal processing (simple grinding), especially when it has no effect on animal product quality and production parameters [50].

An interesting approach to the preparation of the algal feed additive was proposed by Michalak et al. (2011) [43]. The mixture of marine macroalgae (Enteromorpha prolifera and Cladophora sp.) was dried and then enriched with microelement ions (Cu(II), $\mathrm{Zn}(\mathrm{II}), \mathrm{Co}(\mathrm{II}), \mathrm{Mn}(\mathrm{II}), \mathrm{Cr}(\mathrm{III}))$ via 
biosorption. The enriched algae were used instead of mineral salts in laying hens feed, which are traditionally used as a source of minerals.

Seaweeds can also be used in poultry nutrition in the liquid form (as extracts) or as extracted compounds and post-extraction residues. Abou El-naga and Megahed (2018) [53] examined the effect of brown seaweed (Ascophyllum nodosum) liquid in drinking water $(1 \mathrm{~mL} / \mathrm{L}$ ) on broiler chickens' performance and their intestine histology, while Li et al. (2018) tested ulvan extracted from green seaweed (Ulva sp.) as a feed additive for laying hens used at doses of $0.05 \%, 0.1 \%, 0.5 \%, 0.8 \%$ and $1 \%$ [47]. Rendón et al. (2003) proposed to use residue obtained after extraction of alginates from brown seaweed-Macrocystis pyrifera (5\%) in laying hens feeding. This approach allows the utilization of industrial byproducts [56].

Marine macroalgae used as feed additives can partially substitute for the components of the poultry diet such as corn, sorghum, soybean and mineral salts [44,49]. The maximum level of seaweeds inclusion into the feed strongly depends on their chemical composition, mainly mineral profile including also toxic metals [15]. It is recommended that seaweeds level incorporated into the laying hens' diets should not exceed 10\% [44]. Ventura et al. (1994) found that dried Ulva rigida was not a suitable ingredient for poultry diets (chicks, cockerels) when the dose was higher than $100 \mathrm{~g} / \mathrm{kg}$ $(10 \%)$ [41]. As shown in Table 1, the inclusion level of seaweeds in poultry diet is usually lower than $10 \%$.

\section{Enrichment of Poultry Products with Algal Biologically Active Compounds}

Functional ingredients of seaweeds can be incorporated into poultry meat and eggs [54]. Many seaweed species are characterized by a high nutrient availability and the rational chemical composition [75]. Enriched with nutrients, animal products can be recognized as functional food [16,43]. Seaweeds can be used to enrich eggs mainly with polyunsaturated fatty acids (e.g., [44,45,66,70]), pigments (enhancement of yolk color) (e.g., [47,55,70]) and minerals (e.g., [43,56]).

In the case of polyunsaturated fatty acids, marine algae can be used as a direct source of dietary n-3 fatty acids (for example docosahexaenoic acid) and can constitute an efficient alternative to currently used sources of these acids (fish oil, fish meal, flaxseed) which are available for the production of poultry products rich in n-3 [76]. Al-Harthi and El-Deek (2012) showed an apparent association between egg yolk fatty acid profile and fatty acid profile of seaweed-palmitic acid was the main saturated fatty acid, whereas oleic - the main unsaturated fatty acid in the biomass of Sargassum. The inclusion of $6 \%$ of Sargassum (used in different forms-sun-dried, boiled or autoclaved) in the diet increased the content of palmitic acid (16:0) in egg yolk, whereas 3\% additive increased the content of oleic acid (18:1, n-9) [70]. Carrillo et al. (2008) found that egg yolks from seaweed's groups (Macrocystis pyrifera, Sargassum sinicola and Enteromorpha spp.) presented a higher content of total saturated, monounsaturated and polyunsaturated fatty acids, but the content of the total $n-6$ fatty acids in all experimental groups was lower and n-3 fatty acids higher than in the control group. Incorporation of especially M. pyrifera (10\%) in the laying hens' diets is an effective way to increase the content of $n-3$ fatty acids in egg yolks [44]. Carrillo et al. (2012) showed that these seaweeds can increase the eggs storage time and can protect polyunsaturated fatty acids accumulated in these eggs. Green alga-Enteromorpha spp.- -had a protective effect on the content of docosahexaenoic acid (DHA) in eggs, while the brown algae-M. pyrifera and S. sinicola - had a similar effect on the content of eicosapentaenoic acid (EPA). Seaweeds antioxidant compounds such as carotenoids, phenolic compounds and vitamins ( $\mathrm{C}$ and E) can have an efficient antioxidant effect in eggs enriched with n-3 PUFAs [45]. Mandal et al. (2019) revealed that the feed additive produced from red seaweed-Kappaphycus alvarezii-applied in the form of powder at doses $1.25 \%, 1.50 \%$ and $1.75 \%$ significantly lowered yolk lipid oxidation in eggs because of its antioxidant properties attributed to active compounds such as polyphenols, $\beta$-carotene, vitamins $C$ and $E$ and polysaccharide - carrageenan, which are potential free radical scavengers that inhibit the lipid peroxidation [51]. The polyunsaturated fatty acids (ALA, EPA, DHA) are crucial for normal growth and development and can prevent many diseases such as heart disease, diabetes, hypertension, 
arthritis, some types of cancer and other autoimmune and inflammatory disorders [65,77]. Since these fatty acids are not synthesized by humans, they should be included in the daily diet [78].

In the poultry industry, seaweeds being a rich source of minerals, natural pigments, polysaccharides (agar, carrageenans, alginic acid, fucoidan, mannitol and laminaran), polyunsaturated fatty acids, sterols (desmosterol, fucosterol, sargasterol, estigmasterol and beta sitosterol) are also used to reduce eggs' cholesterol content according to the requirements of consumers [44,57]. Al-Harthi and El-Deek (2012) reported that seaweeds with their antioxidant properties and the content of fucoxanthin (xanthophyll from brown seaweeds) may reduce the cholesterol level in eggs [70]. These biologically active compounds exhibit hypocholesterolemic and hypolipidemic properties [44,57,79]. This can imply a beneficial impact on human health [70]. Reduction in cholesterol in eggs is important from the point of view of human nutrition: it reduces the risk of cardiovascular disease [47].

There are many reports in literature that confirm the reduction in cholesterol in eggs after seaweeds application. Carrillo et al. (2012) found that decrease in cholesterol level was dose dependent. The cholesterol content in eggs was reduced as the level of Sargassum spp. (2\%, 4\%, 6\% and 8\%) increased in the hens' diet [57]. Carrillo et al. (2008) showed that among tested seaweeds-Macrocystis pyrifera, Sargassum sinicola and Enteromorpha spp.--supplied at a 10\% dose with sardine oil (2\%) to the feed of hens, only green macroalga reduced the content of cholesterol when compared to the control group [44]. In the work of Al-Harthi and El-Deek (2012) it was demonstrated that Sargassum used in different forms-sun-dried, boiled or autoclaved ( $3 \%$ or $6 \%$ ) as a feed additive for hens-significantly reduced the cholesterol, high-density lipoprotein (HDL) and triglycerides content in yolks when compared with the control group. A higher decrease was also observed when a higher dose $(6 \%)$ of different forms of seaweeds was used. The form of seaweeds influenced the content of the total cholesterol and triglycerides in yolk. Generally, the lowest values of these two parameters were in the case of sun-dried seaweeds. For the $6 \%$ dose of sun-dried seaweeds, the total cholesterol content in yolk was by $25 \%$ lower than in the control group, for boiled seaweeds-by $17 \%$ lower and for autoclaved seaweeds by $10 \%$ lower. In the case of the triglycerides content in yolk, the decrease for $6 \%$ feed additive was as follows: 2.5 times lower for sun-dried than for the control, by $27 \%$ lower for autoclaved than for the control and by $61 \%$ higher for boiled seaweeds than for the control [70].

Similar results were obtained by Rizk et al. (2017) who observed that the application of dried brown, red and green seaweeds in Sinai hens diet ( 0.1 and $0.2 \%)$ resulted in a decreased content of total lipids (especially red seaweeds), total cholesterol (especially red seaweeds) and low-density lipoprotein (LDL) fraction (especially red seaweeds) and triglycerides (especially red and green seaweeds), while HDL cholesterol was significantly increased (especially red seaweeds) in eggs as compared to control. Seaweeds antioxidant properties are attributed to this effect [80]. Zeweil et al. (2019) demonstrated that sun-dried and ground Sargassum cinereum and Ulva fasciata used in the feed of laying Japanese quail hens (doses 1.5\% and 3\%) significantly reduced the content of total lipids and total cholesterol in egg yolk in comparison with the control group, which could be related to their lower levels in blood serum and enhanced total antioxidant capacity [40]. Li et al. (2018) attributed the significant reduction in cholesterol in yolks to polysaccharide ulvan extracted from Ulva sp. which was used as a feed additive at concentrations of $0.05 \%, 0.1 \%, 0.5 \%, 0.8 \%$ and $1 \%$ [47]. The reduction in cholesterol content was probably due to the high content of sulfate in ulvan which has the capacity to decompose cholesterol and has the potential to serve as an antihyperlipidemic agent [79]. Other green macroalga-Enteromorpha prolifera-used in the feed of Highland brown laying hens (1\%, 2\% and 3\%) effectively led to a significant reduction in cholesterol content in eggs [46]. In addition, preparations from red seaweeds can reduce free fatty acids and cholesterol in yolks as it was shown in the case of Kappaphycus alvarezii used as powder at doses of $1.25 \%, 1.50 \%$ and $1.75 \%$ [51]. Zeweil et al. (2019) pointed out that the lessening in egg yolk cholesterol relies on the decline in cholesterol created in the liver. Hence, the decrease in total lipids and total cholesterol can be attributed to the weakening impact of herbal extracts on hepatic 3-hydroxy-3-methylglutaryl coenzyme A (HMG-CoA) reductase that is required to produce cholesterol in the liver [40]. 
Seaweeds are known to serve as a natural pigment in poultry feed and the enhancement of yolk color is reflected by the deposition of algal carotenoids [65]. Owing to their antioxidant properties, these pigments are beneficial not only for poultry, but also for humans [70]. Lutein, fucoxanthin and zeaxanthin are the main algal carotenoids that improve egg coloring [57]. Al-Harthi and El-Deek (2012) reported that fucoxanthin increased the pigmentation of egg yolks [70]. Contrary results were presented by Strand et al. (1998), who found that fucoxanthin, being the major carotenoid in seaweed meal (Fucus serratus and F. vesiculosus), was not transferred to yolks of white leghorn laying hens, but gave rise to the following metabolites: fucoxanthinol, fucoxanthinol 3'-sulfate and paracentrone. Generally, the content of carotenoids in egg yolks increased 12-15 times when compared to the control group [55]. Al-Harthi and El-Deek (2012) reported that the inclusion of brown algae (Sargassum dentifebium) sun-dried, boiled or autoclaved at doses of $3 \%$ and $6 \%$ significantly increased the total carotene, lutein plus zeaxanthin content in egg yolks when compared with the control group [70]. Rendón et al. (2003) showed that the residue after alginate extraction from Macrocystis pyrifera used at a dose of $5 \%$, can be an interesting alternative to poultry feeding as a natural source of egg pigments (xanthophylls, zeaxanthine, capsolutein) and as a factor that improves the content of egg proteins [56]. Ulvan extracted from Ulva sp. applied to the diet of Hy-Line Brown hens at concentrations of $0.5 \%$, $0.8 \%$ and $1 \%$ for 8 weeks significantly deepen the yolk color into red tendency [47]. The effect of different species of seaweeds on the yolk color is presented in Table 1. Usually, yolk color is determined by means of the Roche yolk color fan, e.g., $[35,40,44,55,58]$ or Chroma Meter through the $L^{*} a^{*} b^{*}$ color system (where $L^{*}$ value is a luminance or lightness component, $a^{*}$ value is a chromatic component from green to red (redness) and $b^{*}$ value is the chromatic component from blue to yellow (yellowness) e.g., [43,65]. For identification of carotenoids in egg yolks of laying hens, Strand et al. (1998) applied several analytical techniques such as HPLC, ${ }^{1} \mathrm{H}$ NMR and UV-vis spectrophotometry [55].

Marine macroalgae can enhance not only the lipid profile of yolks and their color, but also their multielemental composition. Michalak et al. (2011) found that seaweeds-Enteromorpha prolifera and Cladophora sp.-enriched with microelements- $\mathrm{Cu}(\mathrm{II}), \mathrm{Zn}(\mathrm{II}), \mathrm{Co}(\mathrm{II}), \mathrm{Mn}(\mathrm{II}), \mathrm{Cr}(\mathrm{III})$ via biosorption-increased the content of elements in eggs when compared to the control group, where inorganic salts were used as a source of these elements. This approach was applied to obtain biofortified eggs [43]. Rendón et al. (2003) showed that the addition of 5\% of residue from Macrocystis pyrifera after alginate extraction to the diet of hens resulted in biofortification of eggs with minerals, especially $\mathrm{K}, \mathrm{Mg}$ and Fe. Eggs from the experimental group contained also higher crude protein, total lipids, but lower cholesterol levels [56].

Much fewer data are provided about the enrichment of poultry meat with biologically active ingredients derived from seaweeds. Bonos et al. (2016) found that the addition of Ascophyllum nodosum $(0.5 \%, 1 \%$ and $2 \%)$ to the diet of broiler chickens did not influence statistically the total saturated, monounsaturated and polyunsaturated fatty acids in the breast or the thigh meat. Only the group of chickens fed with $2 \%$ A. nodosum had a significantly higher content of gamma-linolenic fatty acid $(\mathrm{C} 18: 3, \mathrm{n}-6)$ in chicken breast meat and a significantly lower of eicosenoic fatty acid content (C20:1, n-9) when compared to the control group [54].

\section{Quality of Food Derived from Poultry Feed with Seaweeds}

\subsection{Egg Quality}

Egg quality is a significant criterion for laying hen producers and has essential economic consequences. It results from hens' nutrition and seaweeds used as feed additives can improve egg quality—both physical and biochemical parameters which are crucial for egg producers and consumers. Eggshell quality, which is a visible indicator, is especially important for farmers-higher eggshell weight, thickness and strength will decrease the number of cracked shells. In the case of consumers, eggs with reduced cholesterol content, but also improved yolk color are desired. The egg processing industry requires eggs with intense golden yellow yolks, which are preferred by consumers. Moreover, 
it is advisable to use natural pigments instead of synthetic carotenoids [58]. Seaweeds can be a solution for such a demand as it was mentioned in the previous section. Beside yolk color, seaweed can also influence other egg quality parameters, the examples of which are presented in Table 1 . The percentage increase of a given parameter in the group treated with seaweeds than the control group is presented. It can be clearly stated that seaweeds used as feed additives positively affect yolk color and slightly albumen height and Haugh unit.

In the case of seaweeds, an important issue that should be taken into consideration is egg flavor. Usually, the reduced sensory quality of eggs is reported for hens fed with fish oil. Seaweeds are applied to enhance the content of n-3 fatty acids in yolks and their color to satisfy the consumer's expectation [65]. Carrillo et al. (2008) demonstrated that the inclusion of marine seaweeds-Macrocystis pyrifera, Sargassum sinicola and Enteromorpha spp. (10\% plus $2 \%$ of sardine oil) - to the feed as a source of n-3 fatty acids did not affect egg flavor [44]. In the work of Herber-McNeill and Van Elswyk (1998), eggs from the experimental groups whose hens were fed with marine macroalgae-2.4\% (supplied $200 \mathrm{mg}$ DHA and $69 \mathrm{mg} \beta$-carotene/d) and 4.8\% (400 $\mathrm{mg}$ DHA and $138 \mathrm{mg} \beta$-carotene/d)-received acceptable flavor scores, similar to the control group (corn-soybean without added $n-3$ fatty acids) [65]. Rendón et al. (2003) also proved that egg taste was not affected by the inclusion in poultry diet of the $5 \%$ of the post-extraction residue from Macrocystis pyrifera [56].

Taking into consideration the physical quality of eggs, the positive effect of different species of seaweeds is especially visible in the case of egg weight and shell thickness. Carrillo et al. (2008) indicated that compounds derived from seaweeds seem to increase egg weight when included in the laying hen diet [44]. Kulshreshtha et al. (2014) fed laying hens with the diet supplemented with red seaweeds, either Chondrus crispus or Sarcodiotheca gaudichaudii at levels of $0.5 \%, 1 \%$ and $2 \%$ and showed that the diet with $1 \%$ of Sarcodiotheca gaudichaudii boosted egg-yolk and whole egg weights as compared to the control diet; nevertheless, $0.5 \%$ and $2 \%$ of Sarcodiotheca gaudichaudii administration was not diverse from the control. Furthermore, weights of whole eggs and eggshell were greater with hens that ate $1 \%$ of Chondrus crispus than those which ate $0.5 \%$ and $2 \%$ of Chondrus crispus. The same authors added that egg albumen height, yolk color and shell thickness were not changed due to dietary administration with seaweeds [31]. Choi et al. (2018) found that the supplementation of dry and fermented brown seaweeds (Undaria pinnatifida and Hizikia fusiforme) to the diet of laying hens $(0.5 \%)$ improved egg production but did not affect the egg and eggshell characteristics. The significant improvement of eggshell strength of Hy-Line Brown hens can be accounted for by abundant sulfates in ulvan extracted from Ulva sp. [47]. Laying Japanese quails fed with diets supplemented with sun-dried and ground green (Ulva fasciata) and brown (Sargassum cinereum) seaweeds (1.5\% and 3\%) produced eggs of an improved eggshell thickness, egg yolk weight, index and color when compared to the control and decreased the total lipids and total cholesterol content [40]. Green and brown seaweeds contain different minerals needed for eggshell formation [35]. Wang et al. (2013) reported the improvement of shell thickness of eggs from Highland brown laying hens after the application of Enteromorpha prolifera (1\%, 2\% and 3\%), which probably resulted from the increase in calcium in shell [46]. Al-Harthi and El-Deek (2011) found that enzyme supplementation to the diet containing 6\% of autoclaved Sargassum dentifebium improved eggshell quality while the percentage of shell Ca and P significantly increased [81]. Seaweeds with a high content of easily soluble and digestible calcium can be used at lower concentrations in poultry feeding and can constitute an alternative to limestone, which is the main source of calcium in poultry diet. Higher concentrations of seaweeds can reduce the digestibility of phosphorus, which may lead to reduced skeletal integrity [82]. Bradbury et al. (2012) reported that the high calcium content in calcified seaweeds, included in broilers feed, can improve the bone health status (skeletal integrity) and reduce leg weakness of chickens and their lameness [82]. 
Table 1. Examples of egg quality parameters of poultry feed with seaweeds. (a) Brown; (b) green: (c) red (in comparison with the control group).

\begin{tabular}{|c|c|c|c|c|c|c|c|c|c|c|}
\hline \multicolumn{11}{|l|}{ (a) Brown Seaweeds } \\
\hline Form/Inclusion Level & $\begin{array}{c}\text { Poultry/Age/ } \\
\text { Duration of } \\
\text { Experiment }\end{array}$ & Egg Weight & Yolk Color & Albumen Height & Haugh Unit & Shell Thickness & Shell Weight & Shell Strength & Egg-Shape Index & Ref. \\
\hline $\begin{array}{l}\text { Macrocystis pyrifera, } \\
\text { sun-dried and ground; } \\
10 \% \text { of algae }+2 \% \text { of } \\
\text { sardine oil }\end{array}$ & $\begin{array}{c}\text { Leghorn hens, } 35 \text { weeks } \\
\text { old, } \\
\text { 8-week study }\end{array}$ & $\begin{array}{c}\downarrow \\
3.4 \%\end{array}$ & $\begin{array}{c}\uparrow \\
6.9 \%\end{array}$ & $\begin{array}{c}\uparrow \\
14 \%\end{array}$ & $\begin{array}{c}\uparrow \\
8.4 \%\end{array}$ & $\begin{array}{c}\downarrow \\
7.4 \%\end{array}$ & $\begin{array}{c}\downarrow \\
9.1 \%\end{array}$ & n.a. & n.a. & [44] \\
\hline $\begin{array}{l}\text { Post-extraction residue } \\
\text { from Macrocystis } \\
\text { pyrifera (after alginate } \\
\text { extraction); } 5 \%\end{array}$ & $\begin{array}{l}\text { Leghorn hens, } \\
23 \text { weeks old, } \\
\text { 3-week study }\end{array}$ & $\begin{array}{c}\uparrow \\
1.1 \%\end{array}$ & $\begin{array}{c}\uparrow \\
44 \%\end{array}$ & $\begin{array}{c}\uparrow \\
5.1 \%\end{array}$ & $\begin{array}{c}\uparrow \\
0.4 \%\end{array}$ & $\begin{array}{c}\uparrow \\
3.4 \%\end{array}$ & n.a. & n.a. & n.a. & [56] \\
\hline $\begin{array}{l}\text { Sargassum sinicola, } \\
\text { sun-dried and ground; } \\
10 \% \text { of algae }+2 \% \text { of } \\
\text { sardine oil }\end{array}$ & $\begin{array}{l}\text { Leghorn hens, } \\
35 \text { weeks old, } \\
\text { 8-week study }\end{array}$ & $\begin{array}{c}\downarrow \\
0.5 \%\end{array}$ & $\begin{array}{c}\downarrow \\
6.9 \%\end{array}$ & $\begin{array}{c}\uparrow \\
1.5 \%\end{array}$ & $\begin{array}{c}\uparrow \\
0.5 \%\end{array}$ & $\begin{array}{c}\downarrow \\
0.5 \%\end{array}$ & $\begin{array}{c}\downarrow \\
2.8 \%\end{array}$ & n.a. & n.a. & [44] \\
\hline $\begin{array}{l}\text { Sargassum dentifebium, } \\
\text { sun-dried (S); boiled (B) } \\
\text { and autoclaved (A) } \\
\text { (dried before feeding); } \\
3 \% \text { and } 6 \%\end{array}$ & $\begin{array}{l}\text { Hy-Line laying hens, } \\
23 \text { weeks old, } \\
\text { 19-week study }\end{array}$ & n.a. & $\begin{array}{c}\uparrow \\
\text { S: } 3 \%-11 \%, \\
6 \%-4.8 \% ; \\
\text { B: } 3 \%-4.8 \% \text {, } \\
6 \%-9.7 \% ; \\
\text { A: } 3 \%-0.9 \% \\
6 \%-16 \%\end{array}$ & n.a. & n.a. & n.a. & n.a. & n.a. & n.a. & [70] \\
\hline $\begin{array}{l}\text { Sargassum dentifebium, } \\
\text { sun-dried (S); boiled (B) } \\
\text { and autoclaved (A) } \\
\text { (dried before feeding); } \\
3 \% \text { and } 6 \%\end{array}$ & $\begin{array}{l}\text { Hy-Line laying hens, } \\
23 \text { weeks old, } \\
\text { 19-week study }\end{array}$ & $\begin{array}{c}\uparrow \mathrm{S}: 3 \%-0.2 \%, \\
6 \%-1.0 \% ; \\
\downarrow \mathrm{B}: 3 \%-1.5 \%, \\
6 \%-3.3 \% ; \\
\uparrow \mathrm{A}: 3 \%-1.1 \%, \\
6 \%-0.8 \%\end{array}$ & $\begin{array}{c}\text { S: } 3 \% \downarrow-2.4 \%, \\
6 \% \uparrow-6.1 \% ; \\
\uparrow B: 3 \%-5.5 \%, \\
6 \%-12 \% ; \\
\uparrow A: 3 \%-4.3 \%, \\
6 \%-12 \%\end{array}$ & n.a. & $\begin{array}{c}\uparrow \mathrm{S}: 3 \%-0.2 \%, \\
6 \%-2.6 \% ; \\
\uparrow \mathrm{B}: 3 \%-1.8 \%, \\
6 \%-0.7 \% ; \\
\uparrow \mathrm{A}: 3 \%-0.7 \%, \\
6 \%-1.3 \%\end{array}$ & $\begin{array}{c}\text { S: } 3 \% \uparrow-3.3 \%, \\
6 \% \downarrow-2.6 \% ; \\
\uparrow B: 3 \%-9.2 \%, \\
6 \%-1.2 \% ; \\
\uparrow A: 3 \%-0.5 \%, \\
6 \%-3.3 \%\end{array}$ & n.a. & n.a. & $\begin{array}{c}\text { S: } 3 \% \uparrow-0.1 \%, \\
6 \% \downarrow-1.7 \% ; \\
\downarrow B: 3 \%-0.9 \%, \\
6 \%-1.7 \% \\
\text { A: } 3 \% \downarrow-1.4 \%, \\
6 \% \uparrow-2.0 \%\end{array}$ & [81] \\
\hline $\begin{array}{l}\text { Sargassum cinereum, } \\
\text { sun-dried and ground; } \\
1.5 \% \text { and } 3 \%\end{array}$ & $\begin{array}{c}\text { Laying Japanese quail } \\
\text { hens, } \\
10 \text { weeks old, } \\
14 \text {-week study }\end{array}$ & $\begin{array}{l}\uparrow \uparrow \\
1.5 \%-3.9 \% ; \\
3 \%-3.0 \%\end{array}$ & $\begin{array}{c}\uparrow \uparrow \\
1.5 \%-23.1 \% ; \\
3 \%-23.1 \%\end{array}$ & n.a. & $\begin{array}{c}\downarrow \\
1.5 \%-2.5 \% ; \\
3 \%-3.1 \%\end{array}$ & $\begin{array}{c}\uparrow \\
1.5 \%-4.6 \% \\
3 \%-5.1 \%\end{array}$ & $\begin{array}{c}\downarrow \\
1.5 \%-2.8 \% ; \\
3 \%-2.9 \%\end{array}$ & n.a. & $\begin{array}{c}\uparrow \\
1.5 \%-3.2 \% \\
3 \%-1.6 \%\end{array}$ & [40] \\
\hline $\begin{array}{l}\text { Sargassum spp., } \\
\text { dried and ground; } \\
2 \%, 4 \%, 6 \% \text { and } 8 \%\end{array}$ & $\begin{array}{l}\text { Leghorn hens, } \\
19 \text { weeks old, } \\
\text { 5-week study }\end{array}$ & $\begin{array}{c}\downarrow \downarrow \\
2 \%-1.4 \% ; \\
4 \%-2.1 \% ; \\
6 \%-0.5 \% ; \\
8 \%-2.4 \%\end{array}$ & $\begin{array}{c}\uparrow \\
2 \%-3.8 \% ; \\
4 \%-4.9 \% ; \\
6 \%-9.5 \% ; 8 \%-12 \%\end{array}$ & $\begin{array}{l}\downarrow 2 \%-0.8 \% ; \\
4 \%-1.7 \% ; \\
6 \%-3.2 \% ; \\
8 \%-1.8 \%\end{array}$ & $\begin{array}{c}\downarrow \\
\downarrow \\
2 \%-0.2 \% ; \\
4 \%-0.1 \% ; \\
6 \%-1.2 \% ; \\
8 \%-0.2 \%\end{array}$ & n.a. & n.a. & n.a. & n.a. & [57] \\
\hline
\end{tabular}


Table 1. Cont.

\begin{tabular}{|c|c|c|c|c|c|c|c|c|c|c|}
\hline $\begin{array}{l}\text { Sargassum spp. } \\
\text { sun-dried (S); boiled (B) } \\
\text { and autoclaved (A) } \\
\text { (dried before feeding); } \\
0 \%, 3 \%, 6 \%, 9 \% \\
\text { and } 12 \%\end{array}$ & $\begin{array}{c}\text { Lohman laying hens, } \\
23 \text { weeks old, } \\
19 \text {-week study }\end{array}$ & n.a. & $\uparrow^{*}$ & n.a. & n.a. & n.a. & n.a. & n.a. & n.a. & [58] \\
\hline $\begin{array}{l}\text { Fucus serratus and } \\
\text { F. vesiculosus, dried at } \\
40{ }^{\circ} \mathrm{C} \text { and ground; } 15 \%\end{array}$ & $\begin{array}{l}\text { White Leghorn } \\
\text { laying hens, } \\
\text { 24 weeks old, } \\
\text { 4-week study }\end{array}$ & n.a. & $\begin{array}{c}\uparrow \\
12-15 \text { times more } \\
\text { carotenoids }\end{array}$ & n.a. & n.a. & n.a. & n.a. & n.a. & n.a. & [55] \\
\hline $\begin{array}{l}\text { Undaria pinnatifida, } \\
0.5 \% \text { of seaweed (S) and } \\
\text { fermented seaweed (FS) }\end{array}$ & $\begin{array}{l}\text { Hy-Line Brown } \\
\text { laying hens, } \\
70 \text { weeks old, } \\
\text { 4-week study }\end{array}$ & S: $\uparrow 2 \%$; FS: $\downarrow 0.8 \%$ & S: $1.4 \% ;$ FS: $1.4 \%$ & n.a. & S: $0.5 \% ;$ FS: $0.5 \%$ & S: $\downarrow 25 \%$; FS:-n.c. & n.a. & S: $4.5 \% ;$ FS: $4.5 \%$ & n.a. & [35] \\
\hline $\begin{array}{l}\text { Hizikia fusiforme, } \\
0.5 \% \text { of seaweed (S) and } \\
\text { fermented seaweed (FS) }\end{array}$ & $\begin{array}{l}\text { Hy-Line Brown } \\
\text { laying hens, } \\
70 \text { weeks old, } \\
\text { 4-week study }\end{array}$ & $\begin{array}{c}\text { S: } \uparrow 1.4 \% \text {; FS: } \\
\downarrow \downarrow 0.3 \%\end{array}$ & S: $1.4 \% ;$ FS: $1.4 \%$ & n.a. & S: $1.8 \% ;$ FS: $5.4 \%$ & S:-n.c.; FS: $\downarrow 25 \%$ & n.a. & S: $4.5 \%$; FS: $4.5 \%$ & n.a. & [35] \\
\hline $\begin{array}{l}\text { Ascophyllum nodosum } \\
\left(\text { Tasco }{ }^{\circledR}\right) \text {, } \\
\text { sun-dried and ground; } \\
0.25 \% \text { and } 0.5 \%\end{array}$ & $\begin{array}{l}\text { Lohmann LSL Brown, } \\
\text { 34 weeks old, } \\
\text { 3-week study }\end{array}$ & $\begin{array}{l}\uparrow 0.25 \%-1.1 \% ; \\
\downarrow 0.5 \%-1.7 \%\end{array}$ & n.a. & $\begin{array}{c}\uparrow \\
0.25 \%-2.6 \% \\
0.5 \%-4.6 \%\end{array}$ & n.a. & $\begin{array}{c}\downarrow \\
0.25 \%-0.9 \% ; \\
0.5 \%-1.4 \%\end{array}$ & $\begin{array}{c}\uparrow 0.25 \%-0.5 \% ; \\
\downarrow 0.5 \%-2.8 \%\end{array}$ & n.a. & n.a. & [50] \\
\hline $\begin{array}{l}\text { Brown seaweeds } \\
\text { (species not defined, } \\
\text { dried, } 0.1 \% \text { and } 0.2 \%\end{array}$ & $\begin{array}{l}\text { Sinai hens, } \\
52 \text { weeks old, } \\
\text { 12-week study }\end{array}$ & $\begin{array}{c}\downarrow \\
0.1 \%-4.1 \% ; \\
0.2 \%-4.0 \%\end{array}$ & $\begin{array}{l}\downarrow 0.1 \%-5.1 \% ; \\
0.2 \% \text {-n.c. }\end{array}$ & n.a. & $\begin{array}{c}\downarrow \\
0.1 \%-1.4 \% ; \\
0.2 \%-5.4 \%\end{array}$ & $\begin{array}{c}\downarrow \\
0.1 \%-16 \% ; \\
0.2 \%-7.8 \%\end{array}$ & n.a. & n.a. & $\begin{array}{c}0.1 \%-\text { n.c; } \\
\downarrow 0.2 \%-1.7 \%\end{array}$ & [80] \\
\hline
\end{tabular}


Table 1. Cont

\begin{tabular}{|c|c|c|c|c|c|c|c|c|c|c|}
\hline \multicolumn{11}{|l|}{ (b) Green seaweeds } \\
\hline Form/Inclusion Level & $\begin{array}{l}\text { Poultry/Age/ } \\
\text { Duration of } \\
\text { Experiment }\end{array}$ & Egg Weight & Yolk Color & Albumen Height & Haugh Unit & Shell Thickness & Shell Weight & Shell Strength & Egg-Shape Index & Ref. \\
\hline $\begin{array}{l}\text { Enteromorpha spp., } \\
\text { sun-dried and ground, } \\
10 \% \text { of algae }+2 \% \text { of } \\
\text { sardine oil }\end{array}$ & $\begin{array}{l}\text { Leghorn hens, } \\
35 \text { weeks old, } \\
\text { 8-week study }\end{array}$ & $\begin{array}{c}\downarrow \\
1.4 \%\end{array}$ & $\begin{array}{c}\downarrow \\
19 \%\end{array}$ & $\begin{array}{c}\downarrow \\
12 \%\end{array}$ & $\begin{array}{c}\downarrow \\
9.3 \%\end{array}$ & $\begin{array}{c}\downarrow \\
1.6 \%\end{array}$ & $\begin{array}{c}\downarrow \\
3.6 \%\end{array}$ & n.a. & n.a. & [44] \\
\hline $\begin{array}{l}\text { Enteromorpha prolifera, } \\
1 \%, 2 \% \text { and } 3 \%\end{array}$ & $\begin{array}{l}\text { Highland brown } \\
\text { laying hens, } \\
42 \text { weeks old, } \\
\text { 4-week study }\end{array}$ & $\begin{array}{c}\uparrow \\
1 \%-8.7 \% ; \\
2 \%-6.0 \% ; \\
3 \%-8.1 \%\end{array}$ & $\begin{array}{c}\uparrow \\
1 \%-19 \% ; \\
2 \%-18 \% ; \\
3 \%-25 \%\end{array}$ & n.a. & n.a. & $\begin{array}{c}\uparrow \\
1 \%-2.9 \% \\
2 \%-2.9 \% \\
3 \%-5.7 \%\end{array}$ & n.a. & n.a. & $\begin{array}{c}\uparrow \\
1 \%-0.8 \% ; \\
2 \%-\text { n.c.; } \\
3 \%-\text { n.c. }\end{array}$ & [46] \\
\hline $\begin{array}{l}\text { Ulvan from Ulva sp., } \\
0.05 \%, 0.1 \%, 0.5 \%, 0.8 \% \\
\text { and } 1 \%\end{array}$ & $\begin{array}{l}\text { Hy-Line Brown hens, } \\
61 \text { weeks old, } \\
\text { 8-week study }\end{array}$ & $\begin{array}{c}\downarrow 0.05 \%-0.9 \% ; \\
\uparrow 0.1 \%-0.7 \% ; \\
\downarrow 0.5 \%-0.1 \% ; \\
\downarrow 0.8 \%-0.2 \% ; \\
\downarrow 1 \%-1.2 \%\end{array}$ & $\uparrow *$ & $\downarrow^{*}$ & $\downarrow^{*}$ & n.a. & n.a. & $\uparrow^{*}$ & $\downarrow^{*}$ & [47] \\
\hline $\begin{array}{l}\text { Ulva fasciata, } \\
\text { sun-dried and ground; } \\
1.5 \% \text { and } 3 \%\end{array}$ & $\begin{array}{l}\text { Laying Japanese } \\
\text { quail hens } \\
10 \text { weeks old, } \\
\text { 14-week study }\end{array}$ & $\begin{array}{c}\uparrow \uparrow \\
1.5 \%-3.9 \% \\
3 \%-2.6 \%\end{array}$ & $\begin{array}{c}\uparrow \\
1.5 \%-35 \% ; \\
3 \%-46 \%\end{array}$ & n.a. & $\begin{array}{c}\stackrel{\downarrow}{1.5 \%-2.3 \% ;} \\
3 \%-2.3 \%\end{array}$ & $\begin{array}{l}\uparrow \uparrow \\
1.5 \%-3.5 \% ; \\
3 \%-4.1 \%\end{array}$ & 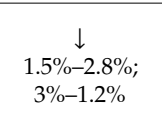 & n.a. & $\begin{array}{c}\uparrow \\
1.5 \%-2.5 \% ; \\
3 \%-0.9 \%\end{array}$ & [40] \\
\hline $\begin{array}{l}\text { Green seaweeds } \\
\text { (species not defined), } \\
\text { dried, } 0.1 \% \text { and } 0.2 \%\end{array}$ & $\begin{array}{c}\text { Sinai hens, } \\
52 \text { weeks old, } \\
\text { 12-week study }\end{array}$ & $\begin{array}{c}\uparrow \\
0.1 \%-4.4 \% \\
0.2 \%-0.9 \%\end{array}$ & $\begin{array}{l}\downarrow 0.1 \%-5.1 \% ; \\
0.2 \% \text {-n.c. }\end{array}$ & n.a. & 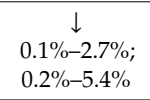 & $\begin{array}{c}\downarrow \downarrow \\
0.1 \%-9.9 \% ; \\
0.2 \%-16 \%\end{array}$ & n.a. & n.a. & $\begin{array}{c}\uparrow \uparrow \\
0.1 \%-1.8 \% ; \\
0.2 \%-0.9 \%\end{array}$ & [80] \\
\hline $\begin{array}{l}\text { Enteromorpha prolifera } \\
\text { and Cladophora sp. } \\
\text { enriched with } \\
\text { microelements (S)-Cu, } \\
\mathrm{Mn}, \mathrm{Zn}, \mathrm{Co}, \mathrm{Cr}\end{array}$ & $\begin{array}{l}\text { Lohmann brown } \\
\text { laying hens, } \\
\text { 30-45 weeks old, } \\
\text { 5-week study }\end{array}$ & $\begin{array}{c}\uparrow \\
\text { S-Cu-3.1\%; } \\
\text { S-Mn-5.7\%; } \\
\text { S-Zn-2.0\%; } \\
\text { S-Co-8.7\%; } \\
\text { S-Cr-1.6\% }\end{array}$ & $\uparrow^{*}$ & n.a. & n.a. & $\begin{array}{c}\uparrow \\
\text { S-Cu-10\%; } \\
\text { S-Mn-14\%; } \\
\text { S-Zn-6.9\%; } \\
\text { S-Co-7.4\%; } \\
\text { S-Cr-5.4\%\% }\end{array}$ & n.a. & n.a. & n.a. & [43] \\
\hline
\end{tabular}


Table 1. Cont.

\begin{tabular}{|c|c|c|c|c|c|c|c|c|c|c|}
\hline (c) Red Seaweeds & & & & & & & & & & \\
\hline Form/Inclusion Level & $\begin{array}{c}\text { Poultry/Age/ } \\
\text { Duration of } \\
\text { Experiment }\end{array}$ & Egg Weight & Yolk Color & Albumen Height & Haugh Unit & Shell Thickness & Shell Weight & Shell Strength & Egg-Shape Index & Ref. \\
\hline $\begin{array}{l}\text { Red seaweeds } \\
\text { (species not defined); } \\
\text { dried, } 0.1 \% \text { and } 0.2 \%\end{array}$ & $\begin{array}{c}\text { Sinai hens, } \\
52 \text { weeks old, } \\
\text { 12-week study }\end{array}$ & $\begin{array}{l}\uparrow 0.1 \%-1.2 \% \\
\downarrow 0.2 \%-7.7 \%\end{array}$ & $\begin{array}{c}\downarrow \\
0.1 \%-5.1 \% ; \\
0.2 \%-5.1 \%\end{array}$ & n.a. & $\begin{array}{c}\downarrow 0.1 \%-6.4 \% \\
0.2 \% \text {-n.c. }\end{array}$ & $\begin{array}{c}\downarrow \\
0.1 \%-9.0 \% ; \\
0.2 \%-7.8 \% \\
\end{array}$ & n.a. & n.a. & $\begin{array}{c}\uparrow \\
0.1 \%-0.5 \% \\
0.2 \%-0.5 \%\end{array}$ & [80] \\
\hline $\begin{array}{l}\text { Chondrus crispus, } \\
\text { raw ground (G: } 4 \% \text { ) and } \\
\text { extruded, dried and } \\
\text { reground (E: } 1 \%, 2 \% \text {, } \\
3 \% \text { and } 4 \% \text { ) }\end{array}$ & $\begin{array}{l}\text { Lohmann Brown Lite } \\
\text { laying hens, } \\
70 \text { weeks old, } \\
\text { 3-week study }\end{array}$ & $\begin{array}{l}\text { G: } \uparrow 4 \%-0.4 \% ; \\
\text { E: } \downarrow 1 \%-1.6 \% ; \\
\text { E: } \downarrow 2 \%-2.0 \% ; \\
\text { E: } \uparrow 3 \%-1.1 \% ; \\
\text { E: } \uparrow 4 \%-0.3 \%\end{array}$ & n.a. & $\begin{array}{l}\text { G: } \uparrow 4 \%-4.2 \% ; \\
\text { E: } \uparrow 1 \%-6.9 \% ; \\
\text { E: } \uparrow 2 \%-2.8 \% ; \\
\text { E: } \uparrow 3 \%-8.3 \% ; \\
\text { E: } \downarrow 4 \%-2.8 \%\end{array}$ & n.a. & $\begin{array}{l}\text { G: } \downarrow 4 \%-2.0 \% ; \\
\text { E: } 1 \%-; \\
\text { E: } \uparrow 2 \%-2.0 \% ; \\
\text { E: } 3 \%-; \\
\text { E: } \uparrow 4 \%-4.0 \%\end{array}$ & $\begin{array}{l}\text { G: } \downarrow 4 \%-0.2 \% \text {; } \\
\text { E: } \downarrow 1 \%-0.5 \% ; \\
\text { E: } \downarrow 2 \%-0.8 \% ; \\
\text { E: } \uparrow 3 \%-0.5 \% ; \\
\text { E: } \uparrow 4 \%-2.9 \%\end{array}$ & n.a. & n.a. & [50] \\
\hline $\begin{array}{l}\text { Kappaphycus alvarezii, } \\
\text { powder; } 1.25 \%, 1.50 \% \\
\text { and } 1.75 \%\end{array}$ & $\begin{array}{l}\text { Laying hens, } \\
\text { day-old, } \\
\text { 40-week study }\end{array}$ & $\begin{array}{c}\uparrow \uparrow \\
1.25 \%-0.7 \% ; \\
1.50 \%-3.8 \% ; \\
1.75 \%-5.3 \% \\
\end{array}$ & $\begin{array}{c}\downarrow \downarrow \\
1.25 \%-10 \% ; \\
1.50 \%-6.6 \% ; \\
1.75 \%-12 \% \\
\end{array}$ & n.a. & $\begin{array}{c}\uparrow \uparrow \\
1.25 \%-0.6 \% ; \\
1.50 \%-4.9 \% ; \\
1.75 \%-5.3 \% \\
\end{array}$ & $\begin{array}{c}\uparrow \uparrow \\
1.25 \%-12 \% ; \\
1.50 \%-9.1 \% ; \\
1.75 \%-12 \% \\
\end{array}$ & n.a. & n.a. & $\begin{array}{c}\uparrow \uparrow \\
1.25 \%-0.3 \% ; \\
1.50 \%-4.7 \% ; \\
1.75 \%-5.2 \%\end{array}$ & [51] \\
\hline $\begin{array}{l}\text { Marine macroalgae } \\
\text { (not defined); } 2.4 \% \text { and } \\
4.8 \%\end{array}$ & $\begin{array}{l}\text { Single Comb } \\
\text { White Leghorn, } \\
56 \text { weeks old, } \\
\text { 4-week study }\end{array}$ & n.a. & $\uparrow *$ & n.a. & n.a. & n.a. & n.a. & n.a. & n.a. & [65] \\
\hline
\end{tabular}




\subsection{Carcass Characteristics and Meat Quality}

In poultry production, broiler chickens are selected for rapid growth, heavier breast weight and increased muscle mass. Many papers examined the effect of seaweeds incorporation into the diet of broilers on their production performance and carcass traits (e.g., $[18,20,28,29,32,33,36,48,49,53,62,63,75,83-88])$. Generally, seaweeds positively influence meat quality, which is usually improved as a consequence of the reduction in fats.

Zahid et al. (2001) showed that broiler chickens (Hubbard) fed on the normal feed containing brown seaweeds $(10 \%, 20 \%, 30 \%$ and $40 \%)$ had higher body weight and a lower amount of fat while higher of protein as compared to controls [83]. Similar results were reported also for brown seaweed-Ascophyllum nodosum - which was added as a liquid to drinking water $(1 \mathrm{~mL} / \mathrm{L})$ of Indian River chicks and significantly increased dressing color, breast width and length and decreased body fat when compared to the control chicks [53]. Much work has been dedicated to other brown seaweed-Sargassum sp. Erum et al. (2017) found that with the increasing level of air-dried and ground Sargassum muticum in the feed, fat pads of the birds were reduced. The carcass quality was improved due to the reduction in fat. In the control group (without algae) and group with $5 \%$ inclusion of S. muticum, the color of fat pads and meat was yellowish. With the increase in S. muticum level till $10 \%$, fat pads were yellowish but minimal, whereas meat-slightly reddish. For the highest dose of S. muticum-15\%-there were no fat pads and the meat was reddish [20]. In the work of Athis Kumar (2018), the consumers evaluated meat parameters such as color, flavor, tenderness, juiciness and taste. Meat from broilers fed with basal diet with the addition of $1 \%$ or $2 \%$ of Sargassum wightii received the highest score. The inclusion of this brown seaweed $(1 \%, 2 \%, 3 \%$ and $4 \%)$ into broiler diet caused the enhancement of carcass traits such as: weight of legs, breast, thigh and dressing. The maximum supplementary effect was noted for Sargassum doses of $1 \%$ and $2 \%$ and was attributed to the chemical composition of this seaweed that contains minerals, vitamins, polyunsaturated fatty acids, essential amino acids, sterols and polysaccharides such as fucoidan [63]. El-Deek et al. (2011) found that different levels $(2 \%, 4 \%$ and $6 \%$ ) of thermally processed Sargassum dentifebium (boiled, autoclaved) in broiler finisher diets had an insignificant effect on the dressing percentage than raw (untreated) algae [62].

In the case of green seaweeds, Wang et al. (2013) showed that the addition of $2 \%, 3 \%$ or $4 \%$ of dry algal powder from Enteromorpha prolifera improved the breast meat quality: the content of fat was significantly reduced, the thickness of subcutaneous fat and abdominal fat rate were decreased [87]. Another green seaweed-Ulva lactuca-was tested as a feed additive in the work of Abudabos et al. (2013). Broiler chickens (male chicks-Ross) which received 3\% of the algal additive had the highest breast muscle yield and dressing percentage whereas abdominal fat was significantly reduced when compared with the group that received the $1 \%$ dose and the control group. The color of breast muscle was not affected by any dietary treatments. Improvement in dressing and breast yield can attributed to the higher content of crude protein and amino acids, specially methionine in the feed with seaweeds [49]. Contrary results were presented by Cañedo-Castro et al. (2019), who showed that there were no significant differences in carcass weight and yield of Arbor Acres broilers fed with different levels of Ulva rigida (air dried and ground) inclusion in the diet $-2 \%, 4 \%$ and $6 \%$ [48].

In the case of red seaweed-Kappaphycus alvarezii-added to the diet of broiler chickens at levels of $0.25 \%, 0.5 \%, 0.75 \%, 1 \%, 1.25 \%$, and $1.5 \%$ there occurred the enhancement of live weight, carcass traits (dressing and eviscerated percentage) and organ weight (heart, liver, gizzard) [18]. A similar effect was also reported for other red seaweeds (Sarcodiotheca gaudichaudii, Chondrus crispus) used as powder in layer hens at doses of $0.5 \%, 1 \%$ or $2 \%$ : no significant effects on liver, spleen, ileum and heart weight [31]. Red algae powder (Chondrus crispus) applied in a feed of male broiler chickens $(0.3 \%)$ significantly improved the carcass and breast yield and decreased the abdominal fat yield [88]. Red seaweed-Polysiphonia spp.-was also introduced to the diet of ducks at doses of $5 \%, 10 \%$ and $15 \%$ and the highest level did not significantly affect the relative weight of dressing, thigh and breast muscles. The relative weight of breast muscles significantly increased when seaweeds 
were applied at $5 \%$ and $10 \%$. Seaweed at a dose of $15 \%$, significantly improved the texture of breast muscles and at doses of $5 \%$ and $10 \%$ improved the texture of thigh muscles. There were no significant differences in the taste, aroma, juiciness and color of meat [37].

\section{Effect of Seaweeds on Poultry Growth and Productive Performance}

\subsection{Growth Performance}

Growth performance in poultry includes live body weight at marketing (BW), average of daily gain (ADG), feed consumption (FC), feed conversion ratio (FCR) and mortality rate. Seaweeds influence growth performance parameters, the examples of which are presented in Table 2. Fermented by-products of brown seaweeds (Undaria pinnatifida) and seaweed fusiforme (Hizikia fusiformis) used at a dose of $0.5 \%$ caused high ADG and FCR and a low mortality rate of broilers when compared with the control group [32]. Erum et al. (2017) indicated that feeding broiler chickens on marine macroalga (Sargassum muticum) as a feed additive (5\%,10\% and $15 \%)$ led to the improvement in BW at marketing, ADG, FC and FCR [20]. The authors indicated that ADG of broilers increased in proportion to the increase in the substitution level of algae; however, birds that received $10 \%$ of algae had the lowest FCR. Athis Kumar (2018) fed broiler chicks on a diet supplemented with Sargassum wightii powder $(1 \%, 2 \%, 3 \%$ and $4 \%$ ) and observed that FCR was boosted from $51.5 \%$ to $51.8 \%$ rather than $33.9 \%$ in the control, while the weight gain was higher in broilers fed with the diet supplemented with $4 \%$ of Sargassum wightii powder, by about $51 \%$ in comparison with the control group. The author attributed the beneficial effects of Sargassum wightii powder to its palatability, high content of nutrients and its ability to enhance digestion and absorption of nutrients in the gut [63]. Bai et al. (2019) indicated that, when compared with the control, dietary supplementation of Laminaria japonica powder (1\%) improved FCR in broiler chicks due to the increased dietary energy content [36]. Ulva rigida was used as a prebiotic in broiler diets $(2 \%, 4 \%$ and $6 \%)$ to enhance growth performance [48]. Non-significant variations in BW were observed, but FC, FCR and the mortality rate presented significant alterations. Feed consumption was greater in broilers that consumed $4 \%$ and $6 \%$ of the prebiotic owing to its attractant properties, while mortality was higher in the control group and in the group of broilers fed with the addition of $6 \%$ of Ulva rigida. Feeding of laying hens (30-45 weeks of age) on diets supplemented with two marine macroalgae (Enteromorpha prolifera and Cladophora sp.) enriched with microelements ( $\mathrm{Cu}, \mathrm{Zn}, \mathrm{Co}, \mathrm{Mn}$ and $\mathrm{Cr}$ ) resulted in a rise in $\mathrm{BW}$ of hens [43]. On the other hand, Islam et al. (2014) stated that ADG and FCR of growing ducks fed on a diet supplemented with sea tangle (Laminaria japonica) did not significantly differ from the control group [30]. In the same line, El-Deek and Brikaa (2009) reported that growing ducks fed with diets supplemented with $4 \%, 8 \%$ and $12 \%$ of red seaweeds (Polysiphonia spp.), irrespective of the diet form (pellet or mash), showed non-significant differences in BW, ADG, FC and FCR [37]. When Japanese quails were fed with the diet supplemented with dried seaweeds (3\%) harvested from the Gulf of Mannar, India (Chetomorpha antennina, Sargassum wightii and Gracilaria corticata), BW and FCR still remained without change [39]. Substituting $1 \%$ and $3 \%$ of corn with green seaweed (Ulva lactuca) in broiler diets resulted in insignificant differences in BWG, cumulative FC and FCR [49]. 
Table 2. Examples of growth performance of poultry fed diets with seaweeds (in comparison with the control group).

\begin{tabular}{|c|c|c|c|c|c|c|}
\hline \multirow{2}{*}{ Seaweeds } & \multirow{2}{*}{ Poultry Species } & \multicolumn{3}{|c|}{ Growth Performance Parameters } & \multirow[b]{2}{*}{ Mortality Rate } & \multirow[b]{2}{*}{ Ref. } \\
\hline & & Final Body Weight & Body Weight Gain & Feed Intake & & \\
\hline \multicolumn{7}{|l|}{ Brown Seaweeds } \\
\hline $\begin{array}{l}\text { Undaria pinnatifida, } \\
0.5 \% \text { of seaweed (S) and fermented } \\
\text { seaweed (FS) }\end{array}$ & $\begin{array}{l}\text { Broilers, } \\
\text { one day old Ross male, } \\
\text { 35-day study }\end{array}$ & $\begin{array}{l}\uparrow(35 \text { day) } \\
\text { S- } 4.3 \% \\
\text { FS- } 2.5 \%\end{array}$ & $\begin{array}{l}\uparrow(35 \text { day) } \\
\text { S-7.6\%; } \\
\text { FS- } 6.4 \%\end{array}$ & $\begin{array}{l}\text { (35 day) } \\
\uparrow S-2.4 \% ; \\
\downarrow F S-2.7 \%\end{array}$ & $\begin{array}{l}\downarrow \\
\text { S- } \sim 4.5 \text { times } \\
\text { FS- } \sim 9 \text { times }\end{array}$ & [32] \\
\hline $\begin{array}{l}\text { Hizikia fusiformis, } \\
0.5 \% \text { of seaweed (S) and fermented } \\
\text { seaweed (FS) }\end{array}$ & $\begin{array}{l}\text { Broilers, } \\
\text { one day old Ross male, } \\
\text { 35-day study }\end{array}$ & $\begin{array}{l}\uparrow(35 \text { day) } \\
\text { S- } 2.2 \% \\
\text { FS }-0.7 \%\end{array}$ & $\begin{array}{l}\uparrow(35 \text { day) } \\
\text { S-4.1\%; } \\
\text { FS }-3.2 \%\end{array}$ & $\begin{array}{l}\downarrow \text { (35 day) } \\
\text { S-1.3\%; } \\
\text { FS-1.5\% }\end{array}$ & $\begin{array}{c}\downarrow \\
\text { S-3 times } \\
\text { FS- } \sim 9 \text { times }\end{array}$ & {$[32]$} \\
\hline $\begin{array}{l}\text { Sargassum muticum, } \\
\text { air dried under the shade and ground; } \\
5 \%, 10 \%, 15 \%\end{array}$ & $\begin{array}{l}\text { Broilers, } \\
\text { one day old, } \\
\text { 39-day study }\end{array}$ & $\begin{array}{c}\uparrow(39 \text { day) } \\
5 \%-23 \% \\
10 \%-25 \% \\
15 \%-26 \%\end{array}$ & $\begin{array}{l}\uparrow(39 \text { day }) \\
5 \%-25 \% \\
10 \%-27 \% \\
15 \%-28 \%\end{array}$ & $\begin{array}{l}\uparrow(39 \text { day) } \\
5 \%-20 \% ; \\
10 \%-14 \% \\
15 \%-17 \%\end{array}$ & n.a. & {$[20]$} \\
\hline $\begin{array}{l}\text { Sargassum wightii, } \\
\text { dried under shade, then sun-dried } \\
\text { and ground, powder; } \\
1 \%, 2 \%, 3 \%, 4 \%\end{array}$ & $\begin{array}{l}\text { Broilers, } \\
\text { one day old, } \\
\text { 121-day study }\end{array}$ & $\begin{array}{c}\uparrow \\
1 \%-88 \% \\
2 \%-93 \% \\
3 \%-93 \% \\
4 \%-93 \%\end{array}$ & $\begin{array}{c}\uparrow \\
1 \%-99 \% ; \\
2 \%-104 \% ; \\
3 \%-104 \% ; \\
4 \%-104 \%\end{array}$ & $\begin{array}{c}\uparrow \\
1 \%-53 \% \\
2 \%-58 \% \\
3 \%-58 \% \\
4 \%-58 \%\end{array}$ & n.a. & {$[63]$} \\
\hline $\begin{array}{l}\text { Sargassum wightii, } \\
\text { dried; } 3 \%\end{array}$ & $\begin{array}{l}\text { Japanese quail, } \\
\text { one day old, } \\
\text { 42-day study }\end{array}$ & $\begin{array}{l}\downarrow \text { (42 day) } \\
3 \%-0.3 \%\end{array}$ & n.a. & n.a. & n.a. & [39] \\
\hline $\begin{array}{l}\text { Sargassum dentifebium, } \\
\text { sun-dried; } 2 \%, 4 \%, 6 \%\end{array}$ & $\begin{array}{l}\text { Broilers, } \\
18 \text { days old, } \\
\text { 39-day study }\end{array}$ & $\begin{array}{l}\downarrow \text { (39 day) } \\
2 \%-1.3 \% \\
4 \%-2.7 \% \\
6 \%-3.3 \%\end{array}$ & $\begin{array}{c}\downarrow \text { (18-39 day) } \\
2 \%-1.5 \% \\
4 \%-3.7 \% \\
6 \%-5.0 \%\end{array}$ & $\begin{array}{c}\uparrow(18-39 \text { day) } \\
2 \%-1.2 \% \\
4 \%-2.5 \% \\
6 \%-5.9 \%\end{array}$ & n.a. & {$[62]$} \\
\hline $\begin{array}{l}\text { Laminaria japonica, } \\
\text { commercial powder and charcoal; } \\
0.1 \%, 0.5 \%, 1 \%\end{array}$ & $\begin{array}{l}\text { Duck, } \\
22 \text { days old, } \\
21 \text {-day study }\end{array}$ & n.a. & $\begin{array}{l}\text { (0-21 days) } \\
0.1 \%-\text { n.c.; } \\
0.5 \%-\text { n.c.; } \\
\uparrow 1 \%-4.8 \%\end{array}$ & $\begin{array}{c}\downarrow(0-21 \text { days }) \\
0.1 \%-0.8 \% ; \\
0.5 \%-2.7 \% \\
1 \%-1.6 \%\end{array}$ & n.a. & [30] \\
\hline
\end{tabular}


Table 2. Cont

\begin{tabular}{|c|c|c|c|c|c|c|}
\hline \multirow{2}{*}{ Seaweeds } & \multirow{2}{*}{ Poultry Species } & \multicolumn{3}{|c|}{ Growth Performance Parameters } & \multirow[b]{2}{*}{ Mortality Rate } & \multirow[b]{2}{*}{ Ref. } \\
\hline & & Final Body Weight & Body Weight Gain & Feed Intake & & \\
\hline $\begin{array}{l}\text { Laminaria japonica, } \\
\text { commercial powder; } 1 \%\end{array}$ & $\begin{array}{l}\text { Arbor Acres broilers, } \\
\text { one day old, } \\
\text { 42-day study }\end{array}$ & n.a. & $\begin{array}{c}\uparrow \\
1 \%-2.7 \%\end{array}$ & $\stackrel{\downarrow}{\downarrow} 1 \%-0.02 \%$ & n.a. & {$[36]$} \\
\hline \multicolumn{7}{|l|}{ Red Seaweeds } \\
\hline $\begin{array}{l}\text { Polysiphonia spp., } \\
\text { dried; } 1.5 \%, 3 \%\end{array}$ & $\begin{array}{l}\text { Hubbard duck, } \\
14 \text { days old, } \\
\text { 56-day study }\end{array}$ & $\begin{array}{c}\downarrow \text { (56 day) } \\
1.5 \%-1.3 \% ; \\
3 \%-3.6 \%\end{array}$ & $\begin{array}{c}\downarrow \\
1.5 \%-1.3 \% ; \\
3 \%-3.8 \%\end{array}$ & $\begin{array}{c}\downarrow \\
1.5 \%-1.7 \% ; \\
3 \%-3.0 \%\end{array}$ & n.a. & {$[52]$} \\
\hline $\begin{array}{l}\text { Gracilaria corticata, } \\
\text { dried; } 3 \%\end{array}$ & $\begin{array}{l}\text { Japanese quail, } \\
\text { one day old, } \\
\text { 42-day study }\end{array}$ & $\begin{array}{l}\uparrow(42 \text { day }) \\
3 \%-0.05 \%\end{array}$ & n.a. & n.a. & n.a. & {$[39]$} \\
\hline $\begin{array}{l}\text { Kappaphycus alvarezii, } \\
0.25 \%, 0.5 \%, 0.75 \%, 1 \%, 1.25 \%, 1.5 \%\end{array}$ & $\begin{array}{l}\text { Broilers, } \\
\text { one day old, } \\
\text { 42-day study }\end{array}$ & n.a. & $\begin{array}{c}\uparrow(0-42 \text { days) } \\
0.25 \%-1.8 \% \\
0.5 \%-2.4 \% \\
0.75 \%-3.0 \% \\
1 \%-2.9 \% \\
1.25 \%-11 \% \\
1.5 \%-9 \%\end{array}$ & $\begin{array}{c}(0-42 \text { days }) \\
\uparrow 0.25 \%-1.3 \% ; \\
\downarrow 0.5 \%-2.6 \% ; \\
\downarrow 0.75 \%-1.4 \% ; \\
\downarrow 1 \%-0.3 \% ; \\
\uparrow 1.25 \%-4.8 \% ; \\
\uparrow 1.5 \%-2.5 \%\end{array}$ & n.a. & {$[18]$} \\
\hline $\begin{array}{l}\text { Palmaria palmata, } \\
\text { dried, ground, commercial; } \\
0.6 \%, 1.2 \%, 1.8 \%, 2.4 \%, 3 \%\end{array}$ & $\begin{array}{l}\text { Ross } 308 \text { broilers, } \\
\text { one day old, } \\
\text { 35-day study }\end{array}$ & $\begin{array}{c}\text { (25-35 day) } \\
\uparrow 0.6 \%-2.0 \% ; \\
\uparrow 1.2 \%-1.0 \% ; \\
\uparrow 1.8 \%-5.3 \% ; \\
\downarrow 2.4 \%-1.7 \% ; \\
\downarrow 3 \%-2.7 \%\end{array}$ & $\begin{array}{c}\text { (25-35 day) } \\
\downarrow 0.6 \%-12 \% ; \\
\downarrow 1.2 \%-9.5 \% ; \\
\downarrow 1.8 \%-9.8 \% ; \\
\downarrow 2.4 \%-3.6 \% ; \\
\downarrow 3 \%-14 \%\end{array}$ & $\begin{array}{c}\text { (25-35 day) } \\
\downarrow 0.6 \%-4.5 \% ; \\
\downarrow 1.2 \%-0.1 \% ; \\
\downarrow 1.8 \%-7.0 \% ; \\
\downarrow 2.4 \%-8.1 \% ; \\
\downarrow 3 \%-5.4 \%\end{array}$ & $\begin{array}{c}\text { (0-35 day) } \\
0.6 \%-\text { lack } \\
\text { mortality; } \\
\downarrow 1.2 \%-33 \% ; \\
1.8 \%-\text { lack } \\
\text { mortality; } \\
\downarrow 2.4 \%-67 \% ; \\
\downarrow 3 \%-67 \%\end{array}$ & [33] \\
\hline
\end{tabular}


Table 2. Cont

\begin{tabular}{|c|c|c|c|c|c|c|}
\hline \multirow{2}{*}{ Seaweeds } & \multirow{2}{*}{ Poultry Species } & \multicolumn{3}{|c|}{ Growth Performance Parameters } & \multirow[b]{2}{*}{ Mortality Rate } & \multirow[b]{2}{*}{ Ref. } \\
\hline & & Final Body Weight & Body Weight Gain & Feed Intake & & \\
\hline \multicolumn{7}{|l|}{ Green Seaweeds } \\
\hline $\begin{array}{l}\text { Ulva rigida, } \\
\text { dried under shade, ground; } \\
2 \%, 4 \%, 6 \%\end{array}$ & $\begin{array}{l}\text { Arbor Acres Broilers, } \\
\text { one day old, } \\
\text { 42-day study }\end{array}$ & $\begin{array}{l}\text { (42 day) } \\
\uparrow 2 \%-0.8 \% ; \\
\downarrow 4 \%-5.5 \% ; \\
\uparrow 6 \%-0.6 \%\end{array}$ & n.a. & $\begin{array}{l}\uparrow(42 \text { day) } \\
2 \%-1.9 \% \\
4 \%-2.6 \% \\
6 \%-4.6 \%\end{array}$ & $\begin{array}{c}\downarrow \\
2 \%-4 \text { times; } \\
4 \%-4 \text { times; } \\
6 \%-17 \%\end{array}$ & [48] \\
\hline $\begin{array}{l}\text { Chetomorpha } \\
\text { antennina, dried; } \\
3 \%\end{array}$ & $\begin{array}{l}\text { Japanese quail, } \\
\text { one day old, } \\
\text { 42-day study }\end{array}$ & $\begin{array}{l}\uparrow(42 \text { day) } \\
3 \%-0.1 \%\end{array}$ & n.a. & n.a. & n.a. & [39] \\
\hline $\begin{array}{l}\text { Ulva lactuca, } \\
\text { sun-dried and then oven-dried, } \\
\text { ground; } 3 \%, 6 \%\end{array}$ & $\begin{array}{l}\text { Ross broilers, } \\
\text { one day old, } \\
\text { 33-day study }\end{array}$ & n.a. & $\begin{array}{c}\text { (19-33 days) } \\
\downarrow 3 \%-0.4 \% ; \\
\uparrow 6 \%-2.3 \%\end{array}$ & $\begin{array}{l}\text { (19-33 days) } \\
\downarrow 3 \%-0.9 \% ; \\
\uparrow 6 \%-2.7 \%\end{array}$ & n.a. & [49] \\
\hline
\end{tabular}




\subsection{Egg Production Performance and Hatchability}

Dietary administration of red seaweed either Chondrus crispus or Sarcodiotheca gaudichaudii at levels of $0.5 \%, 1 \%$ and $2 \%$ had a significant impact on hen-day egg production as found by Kulshreshtha et al. (2014). Hen-day egg production was greater in hens fed with the diet with $2 \%$ of Sarcodiotheca gaudichaudii and 1\% of Chondrus crispus than the control hens [31]. Egg production rate and egg mass were superior $(p<0.05)$ in laying hens that consumed diet supplemented with brown seaweed (Undaria pinnatifida) than those fed with the control or fermented (Undaria pinnatifida) or with non-fermented seaweed (fusiforme-Hizikia fusiformis)-supplemented diets. The hens fed with seaweed fusiforme-supplemented diet and those that ate fermented seaweed fusiforme-supplemented diet had a greater egg production $(p<0.05)$ than the control group (Choi et al. 2018), as a consequence of the high content of brown algae polysaccharides which improved laying performance and immune status [35]. The latter authors also indicated that dietary brown algae inclusion was able to enhance egg-laying performance and the supplementation with fermented seaweeds had no helpful impact on the egg-laying performance.

Egg laying rate in hens was enriched by $4.4 \%$ and $4.3 \%$ as compared to the control when hens consumed diets supplemented with red and green seaweeds $(0.1 \mathrm{~g} / \mathrm{kg}$ diet), during 52-64 weeks of age, thanks to the valuable constituents observed in seaweeds [80]. Ulvan extracted from green seaweed-Ulva-was supplemented in the diet of Hy-Line Brown laying hens (61 weeks old). The findings of this work showed that ulvan at levels from 0.1 to $1 \%$ can enhance egg production, egg weight and eggshell strength [47]. Bratova and Ganovski (1982) stated that consuming diets supplemented with black sea algae had an encouraging impact on hatchability. The maximum percent of hatchability- $87.95 \%$ - was a $6.85 \%$ increase on the control group and can be attributed to the addition of $2 \%$ seaweed to poultry feed [89]. Zeweil et al. (2019) concluded that supplementing dried green and brown seaweeds brought about significantly greater fertility and hatchability percentages than those of the control group [40].

In the study performed by Zeweil et al. (2019), the laying rate of Japanese quails was enhanced by $8.8 \%, 7.2 \%$ and $11.4,9.0 \%$ for birds fed with the diet administrated with green or brown seaweeds at levels of $1.5 \%$ and $3 \%$, correspondingly. The authors also indicated that the same levels of dietary green and brown seaweeds enhanced the hatching rate by $13.3 \%, 16.1 \%, 7.2 \%$ and $15.2 \%$ of total eggs and improved the weight of newly-hatched chicks by $6.4 \%, 14.1 \%, 9.9 \%$ and $12.8 \%$, correspondingly [40]. Dietary incorporation of two marine macroalgae (Enteromorpha prolifera and Cladophora sp.) enriched with microelements in laying hens diet increased the number of eggs in the experimental groups when compared to the control [43].

\section{Effect of Seaweeds on Poultry Health}

Among the huge number of materials that are the source of bioactive compounds in the diet of poultry, seaweeds are a valuable and readily available resource [90] so much so that they are known to influence positively the poultry health. Seaweed extracts have antimicrobial and antiviral properties along with immunomodulatory influences $[31,32,34,36]$. Seaweeds could also be used as prebiotics for improving the production and health status of poultry species [48]. The supplementation of Ulva rigida to broilers diet enhanced the growth of intestinal villi and decreased serum total cholesterol and triglyceride concentrations and can be treated as a prebiotic that can improve broiler health [48]. Polysaccharides are the greatest well-recognized complexes in seaweeds, which underwent multifaceted investigations as a result of their broad bioactivities. The antiviral properties of seaweeds derive from the presence of such bioactive compounds as carrageenan, alginate, fucan and laminaran [91]. Furthermore, these bioactive compounds can prevent the joining or internalization of the virus into the host cells or control DNA repetition and protein production [91,92]. Elizondo-Gonzalez et al. (2012) demonstrated that fucoidan (a sulfated polysaccharide existing in the cell wall matrix of Cladosiphon okamuranus) displayed action against Newcastle disease virus. Fucoidan works in the initial periods of viral infection so as to prevent viral-induced syncytia creation, possibly by blocking the F protein, which is responsible 
for fusion of cell membrane and the viral envelope and through conformational modifications [92]. Villus measurements (width, height and contour length) were higher when Ulva rigida meal was incorporated into broiler diet $(2 \%, 4 \%$ and $6 \%)$ than in the control [48]. Intestinal villus width ranged between 0.6 and $0.7 \mathrm{~mm}$ in broilers which consumed Ulva rigida when compared to the control group $(0.4 \mathrm{~mm})$. The highest values of intestinal villus height $(1.6 \mathrm{~mm})$ and villus contour length $(3.4 \mathrm{~mm})$ were observed in the group fed with $2 \%$ Ulva rigida.

Dietary supplementation of red seaweed-Chondrus crispus-constrained the settlement of Salmonella in the excreta and ceca and this could be caused by an increase in the development of Lactobacillus and raising the level of short chain fatty acids [34]. The same authors also indicated that a greater concentration of IgA in birds fed on diets complemented with Chondrus crispus confirmed the role of macroalgae in the maturation of the immune system. Bai et al. (2019) found that Laminaria japonica powder and antibacterial peptide (cecropin) could be applied as diet inclusion for boosting the immune system of broilers. The dietary inclusion of 3\% of Laminaria japonica powder together with $300 \mathrm{mg} / \mathrm{kg}$ of cecropin enhanced the number of serum Newcastle disease antibody titers and lymphocyte during the fattening period of broilers. The bioactive compounds of Laminaria japonica stimulated lymphocytes, altered their cell structure, which influenced immunity [36]. Choi et al. (2014) concluded that the diet supplemented with $0.5 \%$ of fermented by-products of brown seaweed (Undaria pinnatifida) and seaweed fusiforme (Hizikia fusiformis) activated broiler humoral immunity and supported physical health. Significantly higher concentrations of IgA and IgM and lower of IgG in the serum of broilers fed with seaweeds than in the control group suggested the effectiveness of the feed additive used [32].

Curiously, the nutritional constituents of Laminaria japonica powder may enhance the duplication of Lactobacillus and improve the intestinal microecological setting [93,94]. The inclusion of red seaweeds (Chondrus crispus, Sarcodiotheca gaudichaudii; $2 \%$ or $4 \%$ ) to the diet of laying hens increased the comparative number of helpful microorganisms (Bifidobacterium longum, Lactobacillus acidophilus and Streptococcus salivarius) and reduced the pathogenic microbes (Clostridium perfringens) in the ileal fillings [31,34]. The administration of Laminaria japonica powder mixed with cecropin (extracted from silkworm) extremely constrained Escherichia coli intensification and boosted Lactobacillus development [36]. Laminaria spp. can also enhance humoral immune protection against pathogens $[36,95]$.

Seaweeds can also be used as a feed additive rich in calcium, which can be useful in the treatment of poultry leg weakness and lameness. Supplementation of the broiler diet with a highly digestible marine calcium source, at lower dietary concentration $(0.6 \%)$ may prevent reduced skeletal integrity [82]. Poultry nutrition and the litter quality are the main factors that are responsible for the development of foot pad dermatitis (PFD), which is characterized by ulcerated lesions on the pad of the foot $[9,96]$. Abd El-Wahab et al. (2018) examined the effect of different protein sources (soybean, rapeseed, hemoglobin and algae meal) on the FPD score in broilers (160 one day old). Foot pad dermatitis severity was significantly higher $(p<0.05)$ in birds fed with rapeseed and algae meal in comparison with those fed with soybean or hemoglobin meal. The high FPD score can result from the chemical composition of diet (the high content of sodium—about $2 \mathrm{~g} / \mathrm{kg}$ of dry mass and potassium - about $9 \mathrm{~g} / \mathrm{kg}$ of dry mass) which caused excessive consumption of water. It affected the deterioration of the litter quality [96].

\section{Effect of Seaweeds on Blood Profile}

In broilers that ate diet enriched with Sargassum wightii powder (1\%, $2 \%, 3 \%$ and $4 \%)$, the serum concentration of glucose was augmented from $206.1 \mathrm{mg} / \mathrm{dL}$ (for the dose of $1 \%$ ) to $208.7 \mathrm{mg} / \mathrm{dL}(4 \%$ ) when compared to $204.2 \mathrm{mg} / \mathrm{dL}$ in the control group; total proteins marginally rose from $2.2 \mathrm{mg} / \mathrm{dL}$ in the control group to about $2.3 \mathrm{mg} / \mathrm{dL}$ in all experimental groups. Albumin level increased from $1.7 \mathrm{mg} / \mathrm{dL}(1 \%)$ to $1.92 \mathrm{mg} / \mathrm{dL}(3 \%)$ when compared to $1.1 \mathrm{mg} / \mathrm{dL}$ in the control group and the concentration of globulin decreased from $1.1 \mathrm{mg} / \mathrm{dL}$ in the control group to $0.41 \mathrm{mg} / \mathrm{dL}$ for the dose of $4 \%$. Triglycerides increased from $96.4 \mathrm{mg} / \mathrm{dL}(1 \%)$ to $113.2 \mathrm{mg} / \mathrm{dL}(4 \%)$ instead of $80.3 \mathrm{mg} / \mathrm{dL}$ in the 
control; while the cholesterol level was reduced from $122.1 \mathrm{mg} / \mathrm{dL}$ in the control group to $96.7 \mathrm{mg} / \mathrm{dL}$ ( $3 \%$ and $4 \%$ ). In the case of macroelements, phosphate concentration increased from $7.6 \mathrm{mg} / \mathrm{dL}(1 \%)$ to $8.6 \mathrm{mg} / \mathrm{dL}$ ( $4 \%$ ) when compared to $5.5 \mathrm{mg} / \mathrm{dL}$ in the control group and the calcium level was improved from $11.3 \mathrm{mg} / \mathrm{dL}(1 \%)$ to $12.2 \mathrm{mg} / \mathrm{dL}$ ( $3 \%$ and $4 \%$ ) instead of $10.4 \mathrm{mg} / \mathrm{dL}$ in the control [63]. Using two dietary levels (3\% and 6\%) of brown marine alga (Sargassum dentifebium) processed by various techniques (sun-drying, boiling, autoclaving) reduced the plasma total cholesterol level and lowered the density of the low density lipoprotein (LDL) in laying hens (23-40 weeks of age) than the control group. This decrease was due to the chemical composition of Sargassum dentifebium, which is rich in fiber, sterols and other bioactive compounds with antioxidant properties [70]. The dietary supplementation of $3 \%$ of Laminaria japonica powder combined with $300 \mathrm{mg} / \mathrm{kg}$ cecropin increased lymphocyte numbers in broilers [36].

Frasiska et al. (2016) investigated the impact of the diet containing Gracilaria sp. waste $(10 \%$, $12.5 \%$ and $15 \%$ ) with multi-enzyme additives on lipid profiles of duck (22 weeks old) blood [38]. The authors found that diet with $12.5 \%$ of Gracilaria sp. plus multi-enzyme additive significantly decreased triglycerides, LDL and cholesterol level, but increased the concentration of high density lipoprotein (HDL) in blood, what can be attributed to Gracilaria sp. fiber, which operates as an anticoagulant, antihyperlipidemic, antitumor, antiviral and anti-cholesterol agent [97]. Using $2 \%$ of Ulva rigida meal as a dietary supplementation in broiler diets caused $10 \%-14 \%$ and $15 \%-28 \%$ reductions in the total cholesterol and triglyceride concentrations, respectively, than the control, due to chemical complexes present in algae like, polysaccharides, sterols and polyunsaturated fatty acids [48]. In an experiment conducted by Rizk et al. (2017), supplementation of hen diets with green, brown and red seaweed $(0.1 \%$ and $0.2 \%)$ lowered the concentration of serum total cholesterol, LDL, very low density lipoprotein (VLDL), triglycerides and total lipids, amplified HDL cholesterol and improved serum total protein, albumin, globulin, liver and kidney functions than the control group. The same authors added that hens fed with the diet supplemented with $0.2 \%$ of brown seaweed had significantly higher serum total antioxidant capacity (TAC) and the concentration of glutathione peroxidase (GPX) enzyme, but supplementing the hen diet with $0.2 \%$ of red seaweed significantly increased the activity of serum superoxide dismutase (SOD) enzyme [80]. Similar results were also obtained when Zeweil et al. (2019) fed laying Japanese quail with diets containing green and brown seaweeds at levels of $1.5 \%$ and 3\% [40]. In laying hens fed with the diet enriched with fermented and non-fermented brown algae, Choi et al. (2018) observed that the supplemented-diet groups contained higher albumin concentrations than the control group and the fermented brown seaweed group encompassed higher total cholesterol and triglyceride levels than the other groups. The authors also found that brown seaweed and fermented brown seaweed groups were characterized by upper glutamic pyruvic transaminase activities than the other groups [35].

Abudabos et al. (2013) indicated that serum enzymes and electrolytes were not impacted by the dietary inclusion (1\% and 3\%) of green algae (Ulva lactuca) except for alanine transaminase activity, which was lesser for the groups under consideration [49]. Microelements ( $\mathrm{Cu}, \mathrm{Mn}, \mathrm{Zn}, \mathrm{Co}, \mathrm{Cr}$ and $\mathrm{Fe}$ ) and macroelements ( $\mathrm{Ca}, \mathrm{Mg}$, $\mathrm{Na}$ and $\mathrm{K}$ ) in blood of laying hens fed on the diet enriched with marine macroalgae were higher than in the control group [43]. Sodium concentration in blood serum of laying hens decreased when they ate feed containing $2 \%$ of Sarcodiotheca gaudichaudii and Chondrus crispus when compared to the control [31]. The same authors also found that there was a non-significant impact of red seaweeds on the content of phosphorus, chlorine, calcium, potassium, total protein, glucose, creatine kinase, aspartate amino transferase and uric acid in blood serum.

\section{Advantages and Disadvantages of Seaweeds in Poultry Nutrition and Future Prospects}

When using seaweeds in poultry nutrition, their advantages and disadvantages should be taken into account (Table 3). 
Table 3. Examples of advantages and disadvantages of seaweeds in poultry feeding.

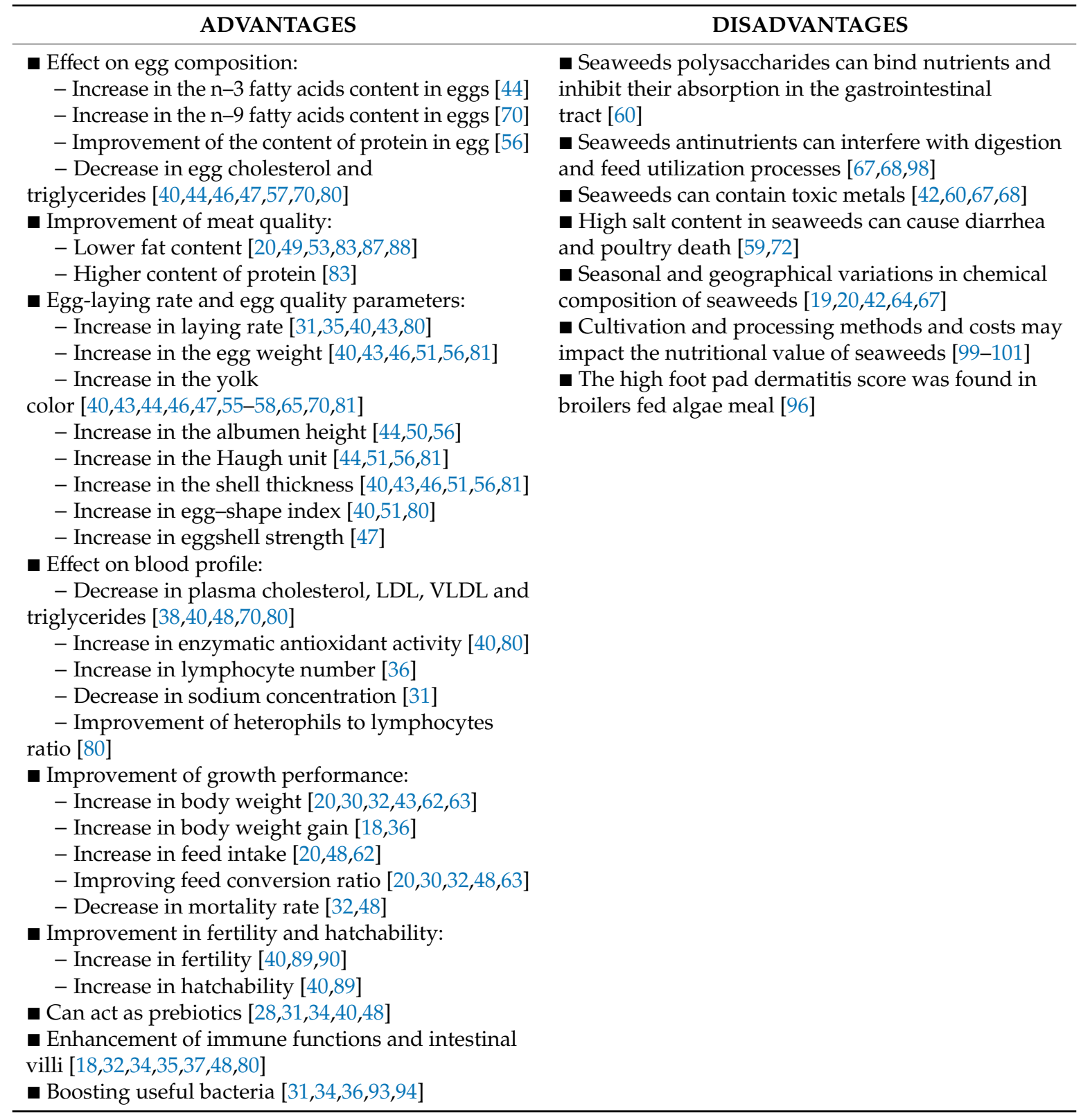

On the basis of the literature reviewed in the present article, it could be concluded that seaweeds at different levels and forms have a positive influence on the growth and performance of poultry as well as their blood profile and health. When seaweeds are added to the feed in the right proportions, at low inclusion levels, they also enrich poultry products (meat, eggs) with biologically active compounds. The use of algae as natural pigments can be of great value for the poultry industry since they can increase yolk color without resorting to synthetic carotenoids. The economic parameters of eggs such as weight, shell weight, thickness and strength are especially important to producers and consumers. As it was shown in the present paper, these parameters can be improved by seaweeds which should have proper chemical composition, lack of toxic metals or compounds that can act as antinutritional factors.

Economic aspects may limit the use of seaweeds in poultry diet. Studies on this problem are scarce. Currently, seaweeds are not grown on a meaningful scale. According to Burg et al. (2012), the total seaweed production expenses, without collection and transportation, are approximately $€ 1,000$ and $€ 1,500$ for each ton of dry matter [101]. Therefore, seaweeds naturally occurring in the environment have the greatest potential to be used as feed additives. The application of seaweeds in 
the sun-dried and ground form is the most beneficial. It was shown that seaweed processing had no significant effect on poultry growth or performance. Each seaweed processing is treated as an added cost. Findings of Zeweil et al. (2019) showed that the Japanese quail fed on diets supplemented with green and brown seaweeds ( $1.5 \%$ and $3 \%$, respectively) generated the greatest net income and relative efficacy (102.5 and 104.2 for green seaweeds and 107.09 and 101.11 for brown seaweeds at the dose of $1.5 \%$ and $3 \%$, consecutively) in comparison with the control group [40]. Seaweeds have the potential to be commonly used as feed additives not only thanks to their properties, but also due to the fact that the search for new, cheaper, safe feed additives is a priority of the poultry industry.

Author Contributions: Conceptualization, I.M. and K.M.; writing-original draft preparation, I.M. and K.M.; writing, review and editing, I.M. and K.M. All authors have read and agreed to the published version of the manuscript.

Funding: I.M. was funded by a grant entitled: "The effect of bioactive algae enriched by biosorption in the certain minerals such as $\mathrm{Cr}(\mathrm{III}), \mathrm{Mg}(\mathrm{II})$ and $\mathrm{Mn}$ (II) on the status of glucose in the course of metabolic syndrome horses. Evaluation in vitro and in vivo" (No 2015/18/E/NZ9/00607) from the National Science Center in Poland (part about seaweeds, biologically active compounds, their forms in animal nutrition).

Conflicts of Interest: The authors declare no conflict of interest.

\section{References}

1. Ahaotu, E.O.; De los Ríos, P.; Ibe, L.C.; Singh, R.R. Climate change in poultry production system-A review. Acta Sci. Agric. 2019, 3, 113-117.

2. United States Department of Agriculture (USDA). Livestock and Poultry: World Markets and Trade. Foreign Agricultural Service, USA. 2020. Available online: https:/apps.fas.usda.gov/psdonline/circulars/ livestock_poultry.pdf (accessed on 27 July 2020).

3. El-Hack, M.E.A.; Mahrose, K.M.; Askar, A.A.; Alagawany, M.; Arif, M.; Saeed, M.; Abbasi, F.; Soomro, R.N.; Siyal, F.A.; Chaudhry, M.T. Single and combined impacts of vitamin A and selenium in diet on productive performance, egg quality, and some blood parameters of laying hens during hot season. Biol. Trace Element Res. 2016, 177, 169-179. [CrossRef] [PubMed]

4. Saeed, M.; El-Hack, M.E.A.; Arif, M.; El-Hindawy, M.M.; Attia, A.I.; Mahrose, K.M.; Bashir, I.; Siyal, F.A.; Arain, M.A.; Fazlani, S.A.; et al. Impacts of distiller's dried grains with solubles as replacement of soybean meal plus vitamin E supplementation on production, egg quality and blood chemistry of laying hens. Ann. Anim. Sci. 2017, 17, 849-862. [CrossRef]

5. Nordhagen, S.; Klemm, R. Implementing small-scale poultry-for-nutrition projects: Successes and lessons learned. Matern. Child Nutr. 2018, 14, e12676. [CrossRef] [PubMed]

6. Daghir, N.J. Poultry Production in Hot Climates, 6th ed.; Cromwell Press: Trowbridge, UK, 1995; pp. 1-12.

7. Alagawany, M.; Mahrose, K.M. Influence of different levels of certain essential amino acids on the performance, egg quality criteria and economics of Lohmann Brown laying hens. Asian J. Poult. Sci. 2014, 8, 82-96. [CrossRef]

8. Farghly, M.F.A.; Mahrose, K.M.; Galal, A.E.; Ali, R.M.; Ahmad, E.A.M.; Rehman, Z.U.; Ullah, Z.; Ding, C. Implementation of different feed withdrawal times and water temperatures in managing turkeys during heat stress. Poult. Sci. 2018, 97, 3076-3084. [CrossRef]

9. Farghly, M.F.A.; Mahrose, K.M.; Cooper, R.; Ullah, Z.; Rehman, Z.U.; Ding, C. Sustainable floor type for managing turkey production in a hot climate. Poult. Sci. 2018, 97, 3884-3890. [CrossRef]

10. El-Hack, M.E.A.; Mahrose, K.M.; Attia, F.A.M.; Swelum, A.A.; Taha, A.E.; Shewita, R.; Hussein, E.-S.O.S.; Alowaimer, A.N. Laying performance, physical, and internal egg quality criteria of hens fed distillers dried grains with solubles and exogenous enzyme mixture. Animals 2019, 9, 150. [CrossRef]

11. Abou-Kassem, D.E.; Ashour, E.A.; Alagawany, M.; Mahrose, K.M.; Rehman, Z.U.; Ding, C. Effect of feed form and dietary protein level on growth performance and carcass characteristics of growing geese. Poult. Sci. 2019, 98, 761-770. [CrossRef]

12. Mahrose, K.M.; El-Hack, M.E.A.; Mahgoub, S.A.; Attia, F.A.M. Influences of stocking density and dietary probiotic supplementation on growing Japanese quail performance. An. Acad. Bras. Cienc. 2019, 91, e20180616. [CrossRef] 
13. Mahrose, K.M.; El-Hack, M.E.A.; Amer, S.A. Influences of dietary crude protein and stocking density on growth performance and body measurements of ostrich chicks. An. Acad. Bras. Cienc. 2019, 91, e20180479. [CrossRef] [PubMed]

14. Rizk, Y.S.; Fahim, H.N.; Beshara, M.M.; Mahrose, K.M.; Awad, A.L. Response of duck breeders to dietary L-Carnitine supplementation during summer season. An. Acad. Bras. Cienc. 2019, 91, e20180907. [CrossRef] [PubMed]

15. Cabrita, A.R.J.; Maia, M.; Oliveira, H.M.; Pinto, I.S.; Almeida, A.; Pinto, E.; Fonseca, A.J.M. Tracing seaweeds as mineral sources for farm-animals. J. Appl. Phycol. 2016, 28, 3135-3150. [CrossRef]

16. Holdt, S.L.; Kraan, S. Bioactive compounds in seaweed: Functional food applications and legislation. J. Appl. Phycol. 2011, 23, 543-597. [CrossRef]

17. Michalak, I.; Chojnacka, K. Algae as production systems of bioactive compounds. Eng. Life Sci. 2015, 15, 160-176. [CrossRef]

18. Qadri, S.S.N.; Biswas, A.; Mandal, A.B.; Kumawat, M.; Saxena, R.; Nasir, A.M. Production performance, immune response and carcass traits of broiler chickens fed diet incorporated with Kappaphycus Alvarezii. J. Appl. Phycol. 2018, 31, 753-760. [CrossRef]

19. Øverland, M.; Mydland, L.T.; Skrede, A. Marine macroalgae as sources of protein and bioactive compounds in feed for monogastric animals. J. Sci. Food Agric. 2018, 99, 13-24. [CrossRef]

20. Erum, T.; Frias, G.G.; Cocal, C.J. Sargassum muticum as feed substitute for broiler. Asia Pacific. J. Educ. Arts Sci. 2017, 4, 6-9.

21. Evans, F.; Critchley, A.T. Seaweeds for animal production use. J. Appl. Phycol. 2014, 26, 891-899. [CrossRef]

22. Makkar, H.; Tran, G.; Heuzé, V.; Giger-Reverdin, S.; Lessire, M.; LeBas, F.; Ankers, P. Seaweeds for livestock diets: A review. Anim. Feed Sci. Technol. 2016, 212, 1-17. [CrossRef]

23. Corino, C.; Modina, S.; Di Giancamillo, A.; Chiapparini, S.; Rossi, R. Seaweeds in pig nutrition. Animals 2019, 9, 1126. [CrossRef] [PubMed]

24. Michalak, I.; Marycz, K. Algae as a promising feed additive for horses. In Seaweeds as Plant Fertilizer, Agricultural Biostimulants and Animal Fodder; Pereira, L., Bahcevandziev, K., Joshi, N.H., Eds.; CRC Press, Taylor \& Francis Group: Boca Raton, FL, USA, 2019; Volume 7, pp. 128-142.

25. Morais, T.; Inácio, A.; Coutinho, T.; Ministro, M.; Cotas, J.; Pereira, L.; Bahcevandziev, K. Seaweed potential in the animal feed: A review. J. Mar. Sci. Eng. 2020, 8, 559. [CrossRef]

26. Haberecht, S.; Wilkinson, S.; Roberts, J.; Wu, S.-B.; Swick, R. Unlocking the potential health and growth benefits of macroscopic algae for poultry. World's Poult. Sci. J. 2018, 74, 5-20. [CrossRef]

27. Kulshreshtha, G.; Hincke, M.T.; Prithiviraj, B.; Critchley, A.T. A Review of the varied uses of macroalgae as dietary supplements in selected poultry with special reference to laying hen and broiler chickens. J. Mar. Sci. Eng. 2020, 8, 536. [CrossRef]

28. Yan, G.L.; Guo, Y.M.; Yuan, J.M.; Liu, D.; Zhang, B.K. Sodium alginate oligosaccharides from brown algae inhibit Salmonella Enteritidis colonization in broiler chickens. Poult. Sci. 2011, 90, 1441-1448. [CrossRef] [PubMed]

29. Wiseman, M. Evaluation of Tasco ${ }^{\circledR}$ as a Candidate Prebiotic in Broiler Chickens; Dalhousie University: Halifax, NS, Canada, 2012; Available online: https://dalspace.library.dal.ca/bitstream/handle/10222/14443/Wiseman_ Melissa_MSc._Animal_Science_February_2012.pdf?sequence=3\&isAllowed=y (accessed on 25 April 2020).

30. Islam, M.M.; Ahmed, S.T.; Mun, H.S.; Kim, Y.J.; Yang, C.J. Effect of Sea Tangle (Laminaria japonica) and charcoal supplementation as alternatives to antibiotics on growth performance and meat quality of ducks. Asian-Australas. J. Anim. Sci. 2014, 27, 217-224. [CrossRef]

31. Kulshreshtha, G.; Rathgeber, B.; Stratton, G.; Thomas, N.; Evans, F.; Critchley, A.T.; Hafting, J.; Prithiviraj, B. Feed supplementation with red seaweeds, Chondrus crispus and Sarcodiotheca gaudichaudii, affects performance, egg quality, and gut microbiota of layer hens. Poult. Sci. 2014, 93, 2991-3001. [CrossRef]

32. Choi, Y.J.; Lee, S.R.; Oh, J.-W. Effects of dietary fermented seaweed and seaweed fusiforme on growth performance, carcass parameters and immunoglobulin concentration in broiler chicks. Asian-Australas. J. Anim. Sci. 2014, 27, 862-870. [CrossRef]

33. Karimi, S.H. Effects of Red Seaweed (Palmaria Palmata) Supplemented Diets Fed to Broiler Chickens Raised under Normal or Stressed Conditions; Dalhousie University: Halifax, NS, Canada, 2015; Available online: https://dalspace.library.dal.ca/bitstream/handle/10222/64662/Karimi--Seyed_Hossein--MSc-September_21.pdf?sequence=3\&isAllowed=y (accessed on 24 April 2020). 
34. Kulshreshtha, G.; Rathgeber, B.; MacIsaac, J.; Boulianne, M.; Brigitte, L.; Stratton, G.; Thomas, N.A.; Critchley, A.T.; Hafting, J.; Prithiviraj, B. Feed supplementation with red seaweeds, Chondrus crispus and Sarcodiotheca gaudichaudii, reduce Salmonella Enteritidis in laying hens. Front. Microbiol. 2017, 8, 567. [CrossRef]

35. Choi, Y.; Lee, E.; Na, Y.; Lee, S. Effects of dietary supplementation with fermented and non-fermented brown algae by-products on laying performance, egg quality, and blood profile in laying hens. Asian-Australasian J. Anim. Sci. 2018, 31, 1654-1659. [CrossRef]

36. Bai, J.; Wang, R.; Yan, L.; Feng, J. Co-Supplementation of dietary seaweed powder and antibacterial peptides improves broiler growth performance and immune function. Braz. J. Poult. Sci. 2019, 21, 1-9. [CrossRef]

37. El-Deekx, A.; Bri, A.M.; Brikaa, A.M. Effect of different levels of seaweed in starter and finisher diets in pellet and mash form on performance and carcass quality of ducks. Int. J. Poult. Sci. 2009, 8, 1014-1021. [CrossRef]

38. Frasiska, N.; Suprijatna, E.; Susanti, S. Effect of diet containing Gracilaria sp. waste and multi-enzyme additives on blood lipid profile of local duck. Anim. Prod. 2016, 18, 22. [CrossRef]

39. Karu, P.; Selvan, S.; Gopi, H.; Manobhavan, M. Effect of macroalgae supplementation on growth performance of Japanese quails. Int. J. Curr. Microbiol. Appl. Sci. 2018, 7, 1039-1041. [CrossRef]

40. Zeweil, S.H.; Abu Hafsa, S.H.; Zahran, S.M.; Ahmed, M.S.; Abdel-Rahman, N. Effects of dietary supplementation with green and brown seaweeds on laying performance, egg quality, and blood lipid profile and antioxidant capacity in laying Japanese quail. Egypt. Poult. Sci. J. 2019, 39, 41-59. [CrossRef]

41. Ventura, M.; Castañon, J.; McNab, J. Nutritional value of seaweed (Ulva rigida) for poultry. Anim. Feed. Sci. Technol. 1994, 49, 87-92. [CrossRef]

42. Michalak, I.; Chojnacka, K. Multielemental analysis of macroalgae from the Baltic Sea by ICP-OES to monitor environmental pollution and assess their potential uses. Int. J. Environ. Anal. Chem. 2009, 89, 583-596. [CrossRef]

43. Michalak, I.; Chojnacka, K.; Dobrzański, Z.; Górecki, H.; Zielińska, A.; Korczyński, M.; Opaliński, S. Effect of macroalgae enriched with microelements on egg quality parameters and mineral content of eggs, eggshell, blood, feathers and droppings. J. Anim. Physiol. Anim. Nutr. 2010, 95, 374-387. [CrossRef]

44. Carrillo-Dominguez, S.; López, E.; Casas, M.M.; Avila, E.; Castillo, R.M.; Carranco, M.E.; Calvo, C.; Pérez-Gil, F. Potential use of seaweeds in the laying hen ration to improve the quality of n-3 fatty acid enriched eggs. J. Appl. Phycol. 2008, 20, 721-728. [CrossRef]

45. Carrillo-Dominguez, S.; Ríos, V.H.; Calvo, C.; Carranco, M.E.; Casas, M.; Pérez-Gil, F. n-3 fatty acid content in eggs laid by hens fed with marine algae and sardine oil and stored at different times and temperatures. J. Appl. Phycol. 2012, 24, 593-599. [CrossRef]

46. Wang, S.; Hui, J.Y.; Hua, W.L.; Hua, Z.F.; Ting, L.Y. Enteromorpha prolifera supplemental level: Effects on laying performance, egg quality, immune function and microflora in feces of laying hens. Chin. J. Anim. Nutr. 2013, 25, 1346-1352.

47. Li, Q.; Luo, J.; Wang, C.; Tai, W.; Wang, H.; Zhang, X.; Liu, K.; Jia, Y.; Lyv, X.; Wang, L.; et al. Ulvan extracted from green seaweeds as new natural additives in diets for laying hens. J. Appl. Phycol. 2018, 30, 2017-2027. [CrossRef]

48. Cañedo-Castro, B.; Piñón-Gimate, A.; Carrillo, S.; Ramos, D.; Casas-Valdez, M. Prebiotic effect of Ulva rigida meal on the intestinal integrity and serum cholesterol and triglyceride content in broilers. J. Appl. Phycol. 2019, 31, 3265-3273. [CrossRef]

49. Abudabos, A.M.; Okab, A.B.; Aljumaah, R.; Samara, E.; Abdoun, K.A.; Al-Haidary, A.A. Nutritional value of green seaweed (Ulva lactuca) for broiler chickens. Ital. J. Anim. Sci. 2013, 12, 28. [CrossRef]

50. Stupart, C.M. Supplementation of Red Seaweed (Chondrus crispus) and Tasco ${ }^{\circledR}$ (Ascophyllum nodosum) in Laying Hen Diets; Dalhousie University: Halifax, NS, Canada, 2019; Available online: https://dalspace.library.dal.ca/bitstream/handle/10222/76824/Stupart--Cassandra--MSc--AGRI--December-2019.pdf?sequence $=5 \&$ isAllowed $=y$ (accessed on 25 April 2020).

51. Mandal, A.B.; Biswas, A.; Mir, N.A.; Tyagi, P.K.; Kapil, D.; Biswas, A.K. Effects of dietary supplementation of Kappaphycus alvarezii on productive performance and egg quality traits of laying hens. J. Appl. Phycol. 2019, 31, 2065-2072. [CrossRef]

52. El-Deek, A.; Brikaa, M.A. Nutritional and biological evaluation of marine seaweed as a feedstuff and as a pellet binder in poultry diet. Int. J. Poult. Sci. 2009, 8, 875-881. [CrossRef] 
53. El-Naga, M.A.; Megahed, M. Impact of brown algae supplementation in drinking water on growth performance and intestine histological changes of broiler chicks. Egypt. J. Nutr. Feed. 2018, 21, 495-507. [CrossRef]

54. Bonos, E.; Kargopoulos, A.; Nikolakakis, I.; Florou-Paneri, P.; Christaki, E. The seaweed Ascophyllum nodosum as a potential functional ingredient in chicken nutrition. J. Oceanogr. Mar. Res. 2017, 4, 140. [CrossRef]

55. Strand, A.; Herstad, O.; Liaaen-Jensen, S. Fucoxanthin metabolites in egg yolks of laying hens. Comp. Biochem. Physiol. Part A Mol. Integr. Physiol. 1998, 119, 963-974. [CrossRef]

56. Rendón, U.; Carrillo, S.; Arellano, L.G.; Casas, M.M.; Pérez, F.; Avila, E. Chemical composition of the residue of alginates (Macrocystis pyrifera) extraction. Its utilization in laying hens feeding. Cuban J. Agricult. Sci. 2003, 37, 287-293.

57. Carrillo, S.; Bahena, A.; Casas, M.; Carranco, M.E.; Calvo, C.C.; Ávila, E.; Pérez-Gi, F. The alga Sargassum spp. as alternative to reduce egg cholesterol content. Cuban J. Agricult. Sci. 2012, 46, 181-186.

58. El-Deek, A.A.; Al-Harthi, M.A. Nutritive value of treated brown marine algae in pullet and laying diets. World Poultry Science Association. In Proceedings of the 19th European Symposium on Quality of Poultry Meat, 13th European Symposium on the Quality of Eggs and Egg Products, Turku, Finland, 21-25 June 2009; pp. 1-12.

59. Dewi, Y.L.; Yuniza, A.; Nuraini; Sayuti, K.; Mahata, M.E. Immersion of Sargassum binderi seaweed in river water flow to lower salt content before use as feed for laying hens. Int. J. Poult. Sci. 2017, 17, 22-27. [CrossRef]

60. Dewi, Y.L.; Yuniza, A.; Sayuti, K.; Mahata, M.E.; Nuraini, N. Fermentation of Sargassum binderi seaweed for lowering alginate content of feed in laying hens. J. World's Poult. Res. 2019, 9, 147-153. [CrossRef]

61. Al-Harthi, M.A.; El-Deek, A.A. Nutrient profiles of brown marine algae (Sargassum dentifebium) as affected by different processing methods for chickens. J. Food Agricult. Environ. 2012, 10, 475-480.

62. El-Deek, A.A.; Al-Harthi, M.A.; Abdalla, A.A.; Elbanoby, M.M. The use of brown algae meal in finisher broiler diets. Egypt. Poult. Sci. 2011, 31, 767-781.

63. Athis Kumar, K. Effect of Sargassum wightii on growth, carcass and serum qualities of broiler chickens. Vet. Sci. Res. 2018, 3, 000156.

64. Fleurence, J. Seaweed proteins: Biochemical, nutritional aspects and potential uses. Trends Food Sci. Technol. 1999, 10, 25-28. [CrossRef]

65. Herber-McNeill, S.M.; Van Elswyk, M.E. Dietary marine algae maintains egg consumer acceptability while enhancing yolk color. Poult. Sci. 1998, 77, 493-496. [CrossRef]

66. González-Esquerra, R.; Leeson, S. Alternatives for enrichment of eggs and chicken meat with omega-3 fatty acids. Can. J. Anim. Sci. 2001, 81, 295-305. [CrossRef]

67. Stengel, D.B.; Connan, S.; Popper, Z.A. Algal chemodiversity and bioactivity: Sources of natural variability and implications for commercial application. Biotechnol. Adv. 2011, 29, 483-501. [CrossRef]

68. Rajauria, G. Seaweeds: A sustainable feed source for livestock and aquaculture. Seaweed Sustain. 2015, 389-420. [CrossRef]

69. Lahaye, M.; Vigouroux, J. Liquefaction of dulse (Palmaria palmata (L.) Kuntze) by a commercial enzyme

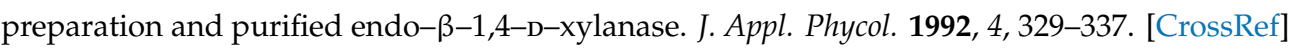

70. Al-Harthi, M.A.; El-Deek, A.A. Effect of different dietary concentrations of brown marine algae (Sargassum dentifebium) prepared by different methods on plasma and yolk lipid profiles, yolk total carotene and lutein plus zeaxanthin of laying hens. Ital. J. Anim. Sci. 2012, 11, 347-353. [CrossRef]

71. Yuan, Y.V. Marine Algal Constituents; Barrow, C., Shahidi, F., Eds.; Marine Nutraceuticals and Functional Foods; CRC: Boca Raton, FL, USA, 2008; pp. 259-296.

72. Zahid, P.B.; Aisha, K.; Ali, A. Green seaweed as component of poultry feed. Bangladesh J. Bot. 1995, 24, 153-156.

73. Charoensiddhi, S.; Abraham, R.E.; Su, P.; Zhang, W. Seaweed and seaweed-derived metabolites as prebiotics. Adv. Food Nutr. Res. 2020, 91, 97-156. [CrossRef]

74. Gibson, G.R.; Beatty, E.R.; Wang, X.; Cummings, J.H. Selective stimulation of bifidobacteria in the human colon by oligofructose and inulin. Gastroenterology 1995, 108, 975-982. [CrossRef]

75. Sun, J.; Song, H.L.; Zhao, J.; Xiao, Y.; Qi, R.; Lin, Y.T. Effects of different dietary levels of Enteromorpha prolifera on nutrient availability and digestive enzyme activities of broiler chickens. Chin. J. Anim. Nutr. 2010, $22,1658-1664$. 
76. Herber, S.M.; Van Elswyk, M.E. Dietary marine algae promotes efficient deposition of n-3 fatty acids for the production of enriched shell eggs. Poult. Sci. 1996, 75, 1501-1507. [CrossRef]

77. Simopoulos, A.P. Human requirement for n-3 polyunsaturated fatty acids. Poult. Sci. 2000, 79, 961-970. [CrossRef]

78. FAO. Fats and Fatty Acids in Human Nutrition. Report of an Expert Consultation; FAO Food and Nutrition: Geneva, Switzerland, 2008.

79. Qi, H.; Sheng, J. The antihyperlipidemic mechanism of high sulfate content ulvan in rats. Mar. Drugs 2015, 13, 3407-3421. [CrossRef]

80. Rizk, Y.S.; Ismail, I.I.; Abu Hafsa, S.H.; Eshera, A.A.; Tawfeek, F.A. Effect of dietary green tea and dried seaweed on productive and physiological performance of laying hens during late phase of production. Egypt. Poult. Sci. 2017, 37, 685-706. [CrossRef]

81. Al-Harthi, M.A.; El-Deek, A.A. The effects of preparing methods and enzyme supplementation on the utilization of brown marine algae (Sargassum dentifebium) meal in the diet of laying hens. Ital. J. Anim. Sci. 2011, 10, 48. [CrossRef]

82. Bradbury, E.J.; Wilkinson, S.J.; Cronin, G.M.; Walk, C.L.; Cowieson, A.J. The effect of marine calcium source on broiler leg integrity. In Proceedings of the 23rd Annual Australian Poultry Science Symposium, Sydney, Australia, 19-22 February 2012; pp. 85-88.

83. Zahid, P.B.; Ali, A.; Zahid, M.J. Brown seaweeds as supplement for broiler feed. Hamdard Med. 2001, $44,98-101$.

84. Koh, T.S.; Im, J.T.; Park, I.K.; Lee, H.J.; Choi, D.Y.; Choi, C.J.; Lee, H.G.; Choi, Y.J. Effect of dietary brown seaweed levels on the protein and energy metabolism in broiler chicks activated acute phase response. J. Anim. Sci. Technol. (Kor.) 2005, 47, 379-390.

85. Ali, A.; Memon, M.S. Incorporation of Enteromorpha procera Ahlner as nutrition supplement in chick's feed. Int. J. Biol. Biotechnol. 2008, 5, 211-214.

86. Aisha, K.; Zahid, P.B. Brown seaweeds as supplementary feed for poultry. Int. J. Phycol. Phycochem. 2009, 5, 17-20.

87. Wang, S.; Shi, X.; Zhou, C.; Lin, Y. Entermorpha prolifera: Effects on performance, carcass quality and small intestinal digestive enzyme activities of broilers. Chin. J. Anim. Nutr. 2013, 25, 1332-1337.

88. Martínez, Y.; Ayala, L.; Hurtado, C.; Más, D.; Rodríguez, R. Effects of dietary supplementation with red algae powder (Chondrus crispus) on growth performance, carcass traits, lymphoid organ weights and intestinal $\mathrm{pH}$ in broilers. Braz. J. Poult. Sci. 2019, 21,1-7.

89. Bratova, K.; Ganovski, K. Effect of Black Sea algae on chicken egg production and on chick embryo development. Vet. Med. Nauki. 1982, 19, 99-105.

90. Vidanarachchi, J.; Mikkelsen, L.L.; Sims, I.; Iji, P.A.; Choct, M. Phytobiotics: Alternatives to antibiotic growth promoters in monogastric animal feeds. Rec. Adv. Anim. Nutr. Aust. 2005, 15, 131-144.

91. Ahmadi, A.; Moghadamtousi, S.Z.; Abubakar, S.; Zandi, K. Antiviral potential of algae polysaccharides isolated from marine sources: A review. BioMed Res. Int. 2015, 2015, 1-10. [CrossRef] [PubMed]

92. Elizondo-Gonzalez, R.; Cruz-Suárez, L.E.; Marie, D.R.; Mendoza-Gamboa, E.; Rodriguez-Padilla, C.; Trejo-Ávila, L.M. In vitro characterization of the antiviral activity of fucoidan from Cladosiphon okamuranus against Newcastle Disease Virus. Virol. J. 2012, 9, 307. [CrossRef] [PubMed]

93. Siahaan, E.A.; Pendleton, P.; Woo, H.-C.; Chun, B.-S. Brown seaweed (Saccharina japonica) as an edible natural delivery matrix for allyl isothiocyanate inhibiting food-borne bacteria. Food Chem. 2014, 152, 11-17. [CrossRef]

94. Radulovich, R.; Umanzor, S.; Cabrera, R.; Mata, R. Tropical seaweeds for human food, their cultivation and its effect on biodiversity enrichment. Aquaculture 2015, 436, 40-46. [CrossRef]

95. Leonard, S.G.; Sweeney, T.; Bahar, B.; Lynch, B.P.; O’Doherty, J.V. Effect of maternal fish oil and seaweed extract supplementation on colostrum and milk composition, humoral immune response, and performance of suckled piglets. J. Anim. Sci. 2010, 88, 2988-2997. [CrossRef]

96. El-Wahab, A.A.; Visscher, C.; Kamphues, J. Impact of different dietary protein sources on performance, litter quality and foot pad dermatitis in broilers. J. Anim. Feed. Sci. 2018, 27, 148-154. [CrossRef]

97. Zhang, Q.; Li, N.; Liu, X.; Zhao, Z.; Li, Z.; Xu, Z. The structure of a sulfated galactan from Porphyra haitanensis and its in vivo antioxidant activity. Carbohydr. Res. 2004, 339, 105-111. [CrossRef] 
98. Francis, G.; Makkar, H.P.; Becker, K. Antinutritional factors present in plant-derived alternate fish feed ingredients and their effects in fish. Aquaculture 2001, 199, 197-227. [CrossRef]

99. Huyghebaert, G.; Ducatelle, R.; Van Immerseel, F. An update on alternatives to antimicrobial growth promoters for broilers. Veter. J. 2011, 187, 182-188. [CrossRef]

100. Buschmann, A.H.; Camus, C.; Infante, J.; Neori, A.; Israel, A.; Hernández-González, M.C.; Pereda, S.V.; Pinchetti, J.L.G.; Golberg, A.; Tadmor-Shalev, N.; et al. Seaweed production: Overview of the global state of exploitation, farming and emerging research activity. Eur. J. Phycol. 2017, 52, 391-406. [CrossRef]

101. van den Burg, S.; Stuiver, M.; Veenstra, F.; Bikker, P.; López Contreras, A.; Palstra, A.; Broeze, J.; Jansen, H.; Jak, R.; Gerritsen, A.; et al. A Triple P Review of the Feasibility of Sustainable Offshore Seaweed Production in the North. Sea; Wageningen UR (University \& Research Centre): Wageningen, The Netherlands, 2012.

(C) 2020 by the authors. Licensee MDPI, Basel, Switzerland. This article is an open access article distributed under the terms and conditions of the Creative Commons Attribution (CC BY) license (http://creativecommons.org/licenses/by/4.0/). 